\title{
Molecular Mechanisms of Cutaneous Inflammatory Disorder: Atopic Dermatitis
}

\author{
Jung Eun Kim ${ }^{1}$, Jong Sic Kim ${ }^{2}$, Dae Ho $\mathrm{Cho}^{3}$ and Hyun Jeong Park ${ }^{2, *}$ \\ 1 Department of Dermatology, St. Paul's Hospital, College of Medicine, The Catholic University of Korea, \\ Seoul 02559, Korea; mdkjeun@naver.com \\ 2 Department of Dermatology, Yeouido St. Mary's Hospital, College of Medicine, \\ The Catholic University of Korea, 62 Yeouido-dong, Yeongdeungpo-gu, Seoul 07345, Korea; rodmann@nate.com \\ 3 Department of Life Science, SookmyungWomen's University, Seoul 140-742, Korea; \\ cdhkor@sookmyung.ac.kr \\ * Correspondence: hjpark@catholic.ac.kr; Tel.: +82-2-3779-1230; Fax: +82-2-783-7604
}

Academic Editor: Chris Jackson

Received: 31 May 2016; Accepted: 26 July 2016; Published: 30 July 2016

\begin{abstract}
Atopic dermatitis (AD) is a multifactorial inflammatory skin disease resulting from interactions between genetic susceptibility and environmental factors. The pathogenesis of AD is poorly understood, and the treatment of recalcitrant $\mathrm{AD}$ is still challenging. There is accumulating evidence for new gene polymorphisms related to the epidermal barrier function and innate and adaptive immunity in patients with AD. Newly-found T cells and dendritic cell subsets, cytokines, chemokines and signaling pathways have extended our understanding of the molecular pathomechanism underlying AD. Genetic changes caused by environmental factors have been shown to contribute to the pathogenesis of $\mathrm{AD}$. We herein present a review of the genetics, epigenetics, barrier dysfunction and immunological abnormalities in AD with a focus on updated molecular biology.
\end{abstract}

Keywords: atopic dermatitis; genetics; epigenomics; barrier; immunologic abnormalities

\section{Introduction}

Atopic dermatitis $(\mathrm{AD})$ is a common chronic inflammatory skin disease. The prevalence of $\mathrm{AD}$ in children is about $10 \%-20 \%$, while the prevalence in adults is approximately $1 \%-3 \%$ worldwide, depending on the different ethnic populations [1]. It is known that most of AD-related genes do not follow Mendelian law, but are highly heritable. Thus, patients with familial history of AD have a higher risk of developing AD [2]. The prevalence of $\mathrm{AD}$ is higher in developed countries, such as those in Western Europe, and much lower in the countries specialized in agriculture, including China and Eastern Europe, rural Africa and Central Asia. This trend is consistent with the hygiene hypothesis [3]. Additionally, $\mathrm{AD}$ patients have various triggering factors and disease courses, which emphasize the influence of inter-individual differences. About $70 \%$ of patients with AD show elevated serum IgE levels with allergic sensitization and are categorized as having extrinsic $A D$, while other patients showing $A D$ lesions with normal serum IgE levels are categorized as having intrinsic $A D$, although both subtypes share common clinical features [4]. Lesional distribution patterns vary depending on the patient's age and disease activity. Whereas food allergens are the main triggering factors in pediatric AD, inhalant allergens are the main cause of AD exacerbation in adults [5]. The symptoms subside in many pediatric patients as they grow. However, some patients show persistent disease courses and tend to have concomitant allergic diseases, such as allergic rhinitis and asthma [6]. Generally diagnosis is made based on relevant clinical history and symptoms of the patients. The key clinical features of AD are pruritus and chronically-relapsing eczematous dermatitis that has a typical morphology and distribution distinct 
to individual age. These features can be used to distinguish AD from other clinical conditions, such as psoriasis and seborrheic dermatitis. Among various diagnostic criteria, Hanifin-Rajka's criteria have been widely used [7]. The treatment strategy of AD mainly depends on the disease severity. At any stage, moisturizer should be properly used, and during flare-ups, topical and/or systemic immunomodulators can be used to control the conditions with different disease severity. The objective SCORing AD (SCORAD) index is widely used to assess AD severity [8]. Mild AD (SCORAD < 15) can be controlled by using moisturizer and topical anti-inflammatory agents, including topical steroids and calcineurin inhibitors [9]. The main treatment option of moderate $(15 \leqslant$ SCORAD $<40)$ to severe $\mathrm{AD}$ (SCORAD $\geqslant 40$ ) includes systemic immunosuppressants, such as steroids, cyclosporine, azathioprine, methotrexate, interferon-gamma (INF- $\gamma$ ), intravenous immunoglobulin, allergen-specific immunotherapy and phototherapy. The known indication for the above therapies is the AD patients with sleep disorders, emotional stress or SCORAD index $>40$. Antihistamines and antimicrobial drugs can be used if needed. Although biologics have been tried to treat AD, the efficacy is limited when compared to that of psoriasis. Adjunctive treatment, such as evening primrose, probiotics and alternative medicines, can be tried in refractory AD patients [9]. However, the ultimate outcome of current treatment modalities is often not satisfactory in severe AD patients and has significant side effects. There is accumulating evidence that the heterogeneity of AD may result from the complex interactions between genetic susceptibility and environment, resulting in decreased skin barrier function, defects in innate immunity and aberrant immune responses to allergens and pathogens. This information offers the potential for individually-tailored therapeutic approaches. Genome-wide association studies (GWAS) and Immunochip analyses have identified several gene polymorphisms, susceptibility loci for $\mathrm{AD}$ and genetic changes caused by environmental factors that may be involved in the pathogenesis of AD. Newly-found T cells and dendritic cell (DC) subsets, cytokines, chemokines and signaling pathways have extended our understanding of the molecular pathomechanism of AD and modified the conventional concept of T helper type 1 (Th1)/T helper type 2 (Th2) imbalance paradigms [10-13]. Recent advances in the understanding of the pathomechanism of AD regarding the barrier dysfunction and immune dysregulation have led to the development of new therapeutic drugs of $\mathrm{AD}$, and the efficacy and safety of these drugs are currently under the investigation. This review summarized the updated pathogenesis of $\mathrm{AD}$ with regard to genetics, epigenetics, epidermal barrier disruption and immunological dysregulation.

\section{Genetics}

Many barrier and immune molecules related to the pathogenesis of AD showed potential genetic polymorphisms that may serve as protective or risk factors for AD (Table 1). Genes associated with epidermal barrier constituents and enzymes that maintain homeostasis have been linked to AD. Filaggrin gene (FLG) mutations are found in $10 \%-50 \%$ of patients with $\mathrm{AD}$, but also in $9 \%$ of the normal population [14-16]. Loss-of-function mutations in FLG are well-known predisposing factors for AD and account for $40 \%$ of the total mutations in these patients. Whereas the frequency of null mutations of FLG is reportedly about $50 \%$ in European patients with moderate to severe $A D$, this frequency is much lower (<27\%) in Asian patients with AD [17-19]. Only about $15 \%$ of patients with mild to moderate AD show the null mutation of FLG, even in European populations [17]. Therefore, FLG deficiency alone seems insufficient to explain epidermal barrier dysfunction in these patients. In addition to various mutations, copy number variation within FLG also increases the risk of AD [20,21], and the levels of filaggrin degradation products in the stratum corneum are correlated with the FLG genotype or copy number and AD severity [21,22]. Hornerin and FLG2 are fused S-100 proteins that are functionally related to FLG. Among patients with FLG2 mutations, African-Americans tend to develop more persistent $\mathrm{AD}$ [23]. A single-nucleotide polymorphism (SNP) in epidermal differentiation complex (EDC) on chromosome 1 and variants of C11orf30 and LRRC32 on chromosome 11 were found to be associated with AD [24]. Small proline-rich protein 3 (SPRR3) is a cornified envelope (CE) precursor protein. Several mutations related to SPRR3 overexpression in patients with AD are associated with 
decreased production of lipid levels and a thinner CE [25,26]. Mattrin encoded by transmembrane protein 79 (TMEM79) regulates lamellar body secretion. The missense mutation rs6684514 of TMEM79 reportedly impairs lamellar body secretion in patients with AD [27-29]. Serine protease inhibitor Kazal-type 5 (SPINK5) encodes the protease inhibitor lymphoepithelial Kazal-type-related inhibitor (LEKTI), which counteracts the activity of epidermal proteases, such as kallikrein-5 in the epidermis. Loss-of-function mutations in SPINK5 are known to cause Netherton syndrome, which has AD manifestations. The rs2303070 T allele of SPINK5 is a risk factor for AD in Taiwanese populations [30]. The E420K LEKTI variant is associated with an increased risk of developing AD through increased TSLP expression and barrier permeability by enhancement of epidermal protease activity and profilaggrin proteolysis [31]. The claudins are key adhesion molecules comprising tight junctions. The claudin-1 (CLDN1) gene haplotype-tagging SNP reportedly has associations with AD in North American populations [32]. The rs9290929 polymorphism, located in CLDN1, reduced the expression of CLDN1 and enhanced the production of IgE after mold exposure [33].

Several gene polymorphisms related to innate and adaptive immunity have been found in patients with AD. These include mutations in pathogen-associated molecular patterns, such as toll-like receptor (TLR) and nucleotide-binding oligomerization domain receptors (NOD) and antimicrobial peptides (AMPs), TSLP and the receptor for TSLP (TSLPR), IL-1 family cytokines and receptor genes, vitamin D pathway genes, the nerve growth factor pathway, Th2 and other cytokine genes and the genes encoding the high affinity IgE receptor (FceRI, FCER1A) [24,34-39]. About $12 \%$ of patients with AD have the (TLR)2 R753Q mutation, and this mutation is associated with the severe AD phenotype and concomitant atopic diseases in certain populations [40-43]. TLR2 A-16934T, TLR4 D299G and A-896G mutations are also associated with severe AD [43,44]. The TLR9 promoter polymorphism, C-1237T, has been reported in patients with intrinsic AD [45]. SNPs in NOD-like receptor 1 genes related to caspase recruitment domain (CARD)4, CARD12, CARD15, NACHT, LRR and PYD domain-containing protein (NALP)1, NALP12 and NOD1 have been associated with AD $[7,46]$. Several SNPs of the human $\beta$-defensin $(h B D) 1$ gene were found to be linked to severe AD with allergic sensitization [47]. TSLP plays a crucial role in DC-driven Th2 responses. A recent study showed that patients with AD with a certain TSLP polymorphism showed eczema herpeticum [48,49]. IL-1 family cytokines play important roles in innate immune responses in patients with $\mathrm{AD}$. While some variants of the $I L-18$ gene and the receptors (IL18RA) are associated with AD [35,50], rs1946518 and rs187238 polymorphisms in the $I L-18$ gene were shown to be the protective factors against the development of AD [51]. Genetic variants in $I L-12$ and $I L-12 R B$, IFN- $\gamma$ genes (IFNG) and IFNGR1 leading to partial IFNGR1 deficiency are related to $\mathrm{AD}$ in patients susceptible to eczema herpeticum [52,53]. Whereas CYP27A1 variants in the vitamin $D$ pathway genes showed a protective effect, other variants are associated with severe $A D$ with eosinophilia and high IgE levels [35,54-56].

Several distinct polymorphisms of IL-4, IL-13 and IL-31 and their receptors were found to influence AD predisposition [34]. Genetic differences in the genes encoding IL-4 and IL-13 were suggested to alter transcriptional activity. The signal transducer and activator of transcription 6 (STAT6) is a key transcription factor in responses mediated by IL-4 and IL-13. STAT6 variants were found to be associated with AD [57,58]. Neonates with the rs324011 polymorphism in the STAT6 had a lower risk of $\mathrm{AD}$ as they showed a reduced number of regulatory $\mathrm{T}$ cells (Tregs) and an increased Th1 response at birth [59]. A common haplotype encoding IL-31 was shown to be a risk factor for intrinsic AD. The rs7977932 G allele of IL31 variants was shown to be a risk factor for AD in Taiwanese populations [30]. The haplotype AAA or GAA of IL-31 was correlated with increased serum levels of IL-31 and severe pruritus in certain populations [60]. The AA genotype of IL-17A was found to be a predisposing factor of severe $\mathrm{AD}$ with concomitant asthma [61]. Other cytokine variants were also identified in patients with AD, including IL-2, IL-5, IL-6, IL-7, IL-9 and IL-10 [50,53,62-68]. Polymorphisms of regulated on activation, normal T cell expressed and secreted (RANTES) and eotaxin were associated with allergen sensitization [69-71]. A haplotype variant of the histamine 4 receptor (H4R) and a copy number variation were found to be associated with AD [72,73]. An SNP of FCER1A 
was reported to be associated with AD in Asians with an elevated serum IgE level [74-76]. The T allele of brain-derived neurotrophic factor gene polymorphism in C270T is associated with intrinsic AD and male sex. Serum brain-derived neurotrophic factor levels were reported to be correlated with the severity of intrinsic AD [77].

Barrier strengthening therapy to improve the barrier defect can be achieved by the proper use of moisturizer. Biologics treatment targeting Th2 immunity could be the best therapeutic option in the future. Duplimumab, anti-IL-4Ra monoclonal antibodies (mAb), has shown promising therapeutic responses in phase III clinical trials [78]. Anti-IL-13 mAb (lebrikizumab and tralokinumab) is currently in phase II clinical trials for AD [79]. Anti-IL-22 mAb (ILV-094), anti-IL-31 (BMS-981164) and anti-IL-31R (CIM331) mAb, anti-TSLP (AMG 157) and anti-TSLPR (MK-8226) mAb have been developed and are currently in phase II, I, II, I and I clinical trials, respectively [80]. OC000459 and other several small molecules that antagonize the chemoattractant receptor-homologous molecule expressed on Th2 cells have been in a phase II clinical trial of AD patients [80].

\section{Epigenetics}

The modern lifestyle and other environmental factors, such as air pollutants and tobacco smoke, have been suggested to be responsible for the high prevalence of $\mathrm{AD}$ since the advent of industrialization. There is accumulating evidence that epigenetic changes in response to these environmental factors contribute to the pathogenesis of AD. These epigenetic mechanisms include DNA methylation, histone modification and microRNA ( $\mathrm{miR}$ ) responsible for barrier function and immunological regulation [81].

Prenatal tobacco smoke exposure is correlated with high-level miR-223 expression and DNA methylation of the FOXP3 locus in cord blood, which are associated with lower Treg numbers. Infants with lower Treg numbers in cord blood at birth had a higher risk of AD during the first three years of life [82,83]. The potential risks of $\mathrm{AD}$ are determined by both the amount of exposure to or composition of the pollutants and the genetic susceptibility of the host [84]. A Taiwanese birth cohort revealed that a gene polymorphism related to a deficiency of the antioxidant enzyme glutathione-S-transferase may explain the individual differences in susceptibility to AD after prenatal tobacco smoke exposure [85].

DNA demethylation of a specific regulatory region of the TSLP gene was significantly associated with TSLP overexpression in lesional skin of patients with AD [81]. Methylation of the TSLP $5^{\prime}$-CpG island was significantly linked with prenatal smoke exposure. The lower degree of such methylation in cord blood leads to TSLP overexpression and subsequent development of AD [86]. DNA methylation of genes related to FceRI and IgE production may modify allergic sensitization in certain patients with AD. In $\mathrm{AD}$-affected patients with high IgE levels, the levels of DNA cytosine methyltransferase 1 transcripts were significantly decreased in peripheral blood mononuclear cells [87]. Overexpression of FceRI on monocytes and DCs in patients with AD was shown to be due to the demethylation of specific regions within the FCER1G locus [88].

Some miRs that are upregulated or downregulated in AD-induced lesions have been identified and involved in the pathogenesis of AD. Exposure to relevant allergens could induce miR-155 expression in AD lesions. Increased miR-155 downregulates cytotoxic T lymphocyte-associated antigen, a negative regulator of $\mathrm{T}$ cell function, which in turn stimulates $\mathrm{T}$ cell proliferation and leads to a sustained inflammatory state [89]. miR-155 also positively modulates the differentiation and function of $\mathrm{T}$ helper type 17 (Th17) cells and is correlated with AD severity [90]. Increased miR-146a expression has been reported in the lesional skin of patients with AD. miR-146a can alleviate AD inflammation by inhibiting nuclear factor $\mathrm{k}$ B-mediated proinflammatory cytokines and chemokines [91]. The forced expression of miR-143 reversed IL-13-induced inhibition of epidermal differentiation by blocking IL-13R $\alpha 1$. Thus, miR-143 may be a potential therapeutic target in AD [92]. However, evidence regarding epigenetics responsible for $\mathrm{AD}$ is still currently limited, and further studies are needed to clarify the gene-environmental interactions and potential therapeutic targets. 
Table 1. Susceptibility genes for skin barrier and immunity in atopic dermatitis.

\begin{tabular}{|c|c|c|c|c|c|c|}
\hline Gene & Locus & Alleles or Mutation & SNP & Population & Disease Severity & Reference \\
\hline \multicolumn{7}{|c|}{ Epidermal Differentiation Complex } \\
\hline FLG & $1 \mathrm{q} 21.3$ & $\begin{array}{c}\text { Loss-of-function } \\
\text { Copy number variation }\end{array}$ & R501X, 2282del4 & $\begin{array}{l}\text { European, Chinese, } \\
\text { Singaporean }\end{array}$ & $\begin{array}{l}\text { Increases the risk of AD } \\
\text { correlated with severity }\end{array}$ & {$[14,16,18-22]$} \\
\hline FLG2 & $1 \mathrm{q} 21.3$ & Premature stop codon & $\begin{array}{c}\text { rs12568784, Q2053del224 } \\
\text { rs16833974 }\end{array}$ & African American & More persistent $\mathrm{AD}$ & [23] \\
\hline \multirow{2}{*}{ SPINK5 } & \multirow{2}{*}{$5 q 31$} & \multirow{2}{*}{ Loss-of-function } & rs $2303070 \mathrm{~T}$ & Taiwanese & Increases the risk of $\mathrm{AD}$ & [30] \\
\hline & & & E420K & Italian & Increases the risk of $\mathrm{AD}$ & [31] \\
\hline SPRR3 & $1 \mathrm{q} 21.3$ & Copy number variation & rs28989168 & German & Increases the risk of $\mathrm{AD}$ & [25] \\
\hline TMEM79 & & Missense mutation & rs6684514 & Ireland & Increases the risk of $\mathrm{AD}$ & [27] \\
\hline \multirow{2}{*}{ claudin-1 } & \multirow{2}{*}{$3 q 28$} & Haplotype-tagging & rs893051 & African American & Increases the risk of $\mathrm{AD}$ & [32] \\
\hline & & AG or GG genotype & rs9290929 & Korean & Mold infection & [33] \\
\hline \multicolumn{7}{|c|}{ Innate Immunity } \\
\hline \multirow[t]{2}{*}{ TLR2 } & 4 & Missense mutation & R753Q & German, Italian & Severe AD & [40] \\
\hline & & $\mathrm{A}$ & $16934 \mathrm{~T}$ & German, Japanese & Severe AD & {$[41,42]$} \\
\hline \multirow[t]{2}{*}{ TLR4 } & 9 & $\mathrm{~N} / \mathrm{A}$ & D299G & Italian & Increased in $\mathrm{AD}$ & [43] \\
\hline & & $896 \mathrm{~A} / \mathrm{G}$ & $\mathrm{N} / \mathrm{A}$ & Ukrainian & $\begin{array}{l}\text { Increased viral } \\
\text { respiratory infections }\end{array}$ & [44] \\
\hline TLR9 & 3 & TT & C-1237T & German & Intrinsic $\mathrm{AD}$ & [45] \\
\hline NOD1 & & $\mathrm{N} / \mathrm{A}$ & $\begin{array}{l}\text { rs2907748 } \\
\text { rs2907749 }\end{array}$ & German & Allergen sensitization & [46] \\
\hline \multirow{2}{*}{$h B D 1$} & \multirow{2}{*}{8} & haplotype CT & rs5743399 & Korean & allergen sensitization & [47] \\
\hline & & $\mathrm{N} / \mathrm{A}$ & rs5743409 & Korean & $\mathrm{AD}$ & [47] \\
\hline TSLP & $5 q 22$ & $\mathrm{C} / \mathrm{T}$ & rs1898671 & European American & Eczema herpeticum & [48] \\
\hline
\end{tabular}


Table 1. Cont

\begin{tabular}{|c|c|c|c|c|c|c|}
\hline Gene & Locus & Alleles or Mutation & SNP & Population & Disease Severity & Reference \\
\hline \multicolumn{7}{|c|}{ Adaptive Immunity } \\
\hline$I L-18$ & $11 q 22$ & G-allele & $\begin{array}{c}\text { rs1946518 } \\
\text { rs187238 }\end{array}$ & Chinese & Low risk of $\mathrm{AD}$ & [51] \\
\hline IL18RAP & $2 q 12$ & $\mathrm{~N} / \mathrm{A}$ & rs6419573 & Japanese & Increase the risk of $\mathrm{AD}$ & [35] \\
\hline$I L-12$ & chr3 & $\begin{array}{c}\text { IVS-798A/T, haplotype } \\
\text { TA }\end{array}$ & $\begin{array}{l}\text { rs582504, rs582054, } \\
\text { rs2243151 }\end{array}$ & Korean & Increase the risk of $\mathrm{AD}$ & [53] \\
\hline$I L-12 R B$ & $\begin{array}{l}\text { chr5 } \\
\text { chr1 }\end{array}$ & $\begin{array}{l}\text { TT } \\
\text { AA } \\
\end{array}$ & rs438421, rs2066446 & Korean & Allergen sensitization & [53] \\
\hline IFNG/IFNGR1 & $12 / 6 \mathrm{q} 23-24$ & Loss-of-function & V14M and Y397C & African American & Eczema herpeticum & [52] \\
\hline$I L-4$ & $5 q 31-33$ & T allele & $\begin{array}{l}590 \mathrm{C} / \mathrm{T} \text { of IL-4 } \\
\text { promoter }\end{array}$ & Egyptian & Increase the risk of $\mathrm{AD}$ & [58] \\
\hline$I L-4 R \alpha$ & 16 & Gain of function & I50V, Q576R & Egyptian & Increase the risk of AD & [58] \\
\hline$I L-13$ & $5 q 31.1$ & $\mathrm{~N} / \mathrm{A}$ & rs12188917 & & Association with asthma & [34] \\
\hline STAT6 & 12 & $\begin{array}{c}\text { Minor allele } \\
\text { homozygotes }\end{array}$ & rs324011 & German & Low risk of $\mathrm{AD}$ & [59] \\
\hline$I L-31$ & 12 & $\begin{array}{c}\text { Haplotype AAA and } \\
\text { GAA }\end{array}$ & $\begin{array}{c}1066,-2057, \text { and ivs } 2+ \\
12\end{array}$ & polish & $\begin{array}{l}\text { High IL-31 serum level } \\
\text { severe pruritus }\end{array}$ & {$[60]$} \\
\hline$I L-17 A$ & & AA genotype & $152 \mathrm{G} / \mathrm{A}$ & polish & $\begin{array}{l}\text { Severe AD in } \\
\text { coexistence of asthma }\end{array}$ & {$[61]$} \\
\hline FCER1A & 1 & N/A & promoter & Japanese & Allergen sensitization & [74] \\
\hline Chemokines & & N/A & & & & \\
\hline \multirow{2}{*}{ RANTES } & \multirow{2}{*}{17.35} & $28 \mathrm{G}$ & N/A & German & Allergen sensitization & [69] \\
\hline & & 403A overexpression & $\mathrm{N} / \mathrm{A}$ & Japanese, German & Allergen sensitization & [70] \\
\hline \multicolumn{7}{|c|}{ Vitamin D Pathway } \\
\hline Cyp24a1 & $20 q 54$ & Major C allele & rs2248359 & German & Severe AD & [55] \\
\hline$V D R$ & $20 \mathrm{q} 13$ & AT & rs7975232 & Chinese & $\begin{array}{l}\text { Severe, eosinophilia and } \\
\text { high IgE levels }\end{array}$ & [54] \\
\hline \multicolumn{7}{|c|}{ Nerve Growth Factor Pathway } \\
\hline BDNF & 11 & $\mathrm{~T}$ & $\mathrm{C} 270 \mathrm{~T}$ & Chinese & $\begin{array}{l}\text { Intrinsic AD } \\
\text { and male sex }\end{array}$ & [77] \\
\hline
\end{tabular}




\section{Barrier Dysfunction}

Impaired epidermal barrier function in $A D$ is characterized by abnormalities in skin microenvironment, gene functioning epidermal structural proteins, such as filaggrin and claudin, and lipid synthesis. The disrupted barrier causes an increased trans-epidermal water loss and enables the capture of more allergens, thus promoting allergic sensitization and initiation or exacerbation of AD inflammation. Impaired barrier function causes increased IL-1 release from keratinocytes, which activates the vascular endothelium to induce adhesion molecule expression and promotes cutaneous inflammation [12,93]. Epicutaneous sensitization to allergens causes heightened allergic immune responses and serves as a predisposing factor for a more severe allergic march.

The use of soap and detergent raises skin $\mathrm{pH}$ in $\mathrm{AD}$ patients, which induces the imbalance between serine proteases and protease inhibitors. The activities of endogenous and exogenous proteases from house dust mites or S. aureus are increased in AD lesions. Lack of endogenous protease inhibitor activity accelerates barrier permeability and inflammation. Increases in $\mathrm{pH}$ and in serine protease activity result in increased microbial colonization and accelerated degradation of the ceramide synthesis enzymes [94]. In a LEKTI-knockout mouse model, increased kallikrein-5 stimulated proteinase-associated receptor-2 (PAR2), which activates nuclear factor $\mathrm{\kappa}$ B-induced overexpression of thymic stromal lymphopoietin (TSLP) and induces pruritus [95]. TSLP also suppresses the expression of EDC proteins, such as filaggrin, by activating STAT3 and extracellular signal-regulated kinase (ERK) signaling in keratinocytes [96]. Phosphodiesterase 4 (PDE4), which catalyzes the conversion of cyclic adenosine $3^{\prime}, 5^{\prime}$-monophosphate (cAMP) to $5^{\prime}$-AMP, contributes to the pathogenesis of AD via PAR2. Anti-PDE4 agents could theoretically inhibit PAR2 and leukotriene B4 production mediated by increased cAMP levels, thus relieving pruritus in AD [97]. However, the oral anti-PDE4 apremilast and topical anti-PDE4 crisaborole showed limited efficacy in treating AD [98,99].

Filaggrin, a key protein in the skin barrier, is involved in cornification and hydration. FLG deficiency is known to increase [13] and impair skin integrity, hydration, protease activity and AMP function [12]. Reduced levels of hornerin and filaggrin-2 expression were suggested to be related to abnormal cornified envelope (CE) formation in AD skin [100]. In addition to filaggrin, loricrin is a component of $\mathrm{CE}$, and decreased loricrin levels are observed in patients with $\mathrm{AD}$. Filaggrin expression is restored after topical anti-inflammatory treatment with calcineurin inhibitors or corticosteroids [12,101]. A recent study demonstrated that JTC801, a new synthetic compound, increased filaggrin expression in human keratinocytes in vitro and decreased the development of AD-like lesions in mice in vivo [102]. The importance of barrier strengthening therapy is supported by the outcome that a topical recombinant filaggrin delivery through cell penetrating peptide could restore the AD-like inflammation in filaggrin knockout mice [103]. Defects of tight junction proteins, such as claudin, could have a permissive effect on the entry of irritants, allergens or pathogens into the epidermis $[33,104]$. The claudin-1 level showed an inverse correlation with a high serum IgE level and eosinophilia. Claudin-1 expression was significantly suppressed by IL-4, IL-13 and IL-31 in a human skin equivalent [105]. While claudin-1 knockout is lethal, low claudin-1-expressing conditioned mice exhibited AD-like dermatitis and an increased recruitment of neutrophil and macrophage in the skin. TLR2 activation increased the expression of tight junction proteins, including claudin-1, in human keratinocytes. TLR2-deficient mice showed slow and incomplete barrier recovery by suppressing the tight junction proteins [106]. Patients with AD show impaired skin integrity and subclinical inflammation even in uninvolved skin. Consistent with these features, markedly reduced levels of filaggrin, filaggrin-2 and claudin-1 expression were observed not only in lesional AD skin, but also in non-lesional skin in patients with AD [107].

Lipids in the stratum corneum comprise ceramides, free fatty acids (FFAs) and cholesterol. An overall reduction in lipid levels, especially in the ceramide content, and a reduced ceramide chain length are observed in patients with $\mathrm{AD}$ and are associated with the severity of $\mathrm{AD}$ [108]. A decrease in the FFA chain length and an increase in the proportion of unsaturated FFAs have been found in patients with AD [109]. A decreased lipid content leads to a less compact lipid organization and 
defective skin barrier function [109]. Th2-dominant cytokine profiles in AD further contribute to the decrease in ceramide and long-chain FFA levels [28,110].

\section{Immunological Abnormalities}

\subsection{Innate Immunity}

Patients with AD develop recurrent skin infections. Early studies suggested that suppressed levels of AMPs, such as hBD-2, hBD-3 and cathelicidin, in AD-affected skin compared to the skin of patients with psoriasis or healthy subjects, are responsible for this susceptibility to infection [111]. IL-4, IL-13, IL-10 and IL-33 could suppress the expression of hBD-2 and hBD-3 [112], contributing to superinfection [110]. In contrast, recent data showed that the levels of AMPs in AD lesions are increased as much as those in healthy subjects, but are still insufficient to defend against $S$. aureus infection, possibly because of the huge amount of $S$. aureus colonization or functional defects in the AMPs [113]. Members of the S100 protein family (S100A7, S100A8 and S100A9) function as AMPs, as well as damage-associated molecular pattern molecules, which have proinflammatory activities. The levels of S100 proteins are increased in patients with acute and chronic AD, and their proinflammatory properties may result in defects of epidermal differentiation and cutaneous inflammation $[113,114]$.

TLRs play important roles in innate immunity by recognizing PAMP and antimicrobial defenses. The activation of TLRs induces the expression of antimicrobial effector molecules and the release of various proinflammatory and immunomodulatory cytokines, which lead to the activation of adaptive immune responses. In $\mathrm{AD}$, enhanced Th2 cytokines were found to downregulate the expression of TLRs, which renders AD skin more susceptible to skin infections. Several TLR polymorphism have been reported to be associated with AD. Monocytes from patients with AD with the TLR2 R753Q mutation show enhanced IL- 6 and IL-12 production and downregulated CD36 expression. These abnormalities cause impaired TLR2/TLR6 heterodimer-CD36 complex internalization, leading to increased susceptibility to Staphylococcus aureus (S. aureus) infection [115]. Vitamin D contributes to cathelicidin and lipid synthesis, and the efficacy of vitamin D supplementation has been suggested in small studies $[116,117]$. Several SNP polymorphism in vitamin D could affect TLR activity by inhibiting the cathelicidin expression $[55,56]$.

The main sources of TSLP are epidermal keratinocytes, and the TSLP level is increased in the epidermis of AD lesions. TSLP is involved in the activation of Langerhans cells (LCs) and DCs to induce Th2 immune responses. TSLP showed a positive correlation with IL-31 and IL-33 and has been suggested as new biomarker in $\mathrm{AD}$ [118].

\subsection{Adaptive Immunity}

\subsubsection{Th1/Th2 Imbalance}

Skin-homing memory $\mathrm{T}$ cells are key players of immune dysregulation in the pathogenesis of AD. Traditionally, the main pathogenesis of AD has been interpreted as immune dysregulation with predominant Th2 cytokines, such as IL-4, IL-5 and IL-13. As new T cell subsets were identified, the view of AD was modified as a Th2/Th22 polarized environment. Acute lesions of AD are driven by Th2 and Th22 responses, while chronic lesions are driven by a Th1 response. A recent study confirmed $\mathrm{AD}$ to be a result of Th2-skewed immune response, specifically the ratio of Th1:Th2 of chronic AD was 0.09 . Consistently, most of the $\mathrm{CD}^{+} \mathrm{T}$ cells in biopsy specimens from chronic AD lesions were comprised of Th2 (64.6\%), followed by Th17 (30.4\%), Th22 (3.3\%) and Th1 cells (4.8\%) [119].

The Th2 cytokines IL-4 and IL-13 have a permissive effect on microbial invasion and epidermal barrier disruption by inhibiting AMP production [120], reducing lipid production in the stratum corneum and inducing spongiosis [80]. Th2 cytokines downregulate the expression of the major EDC genes, including FLG, LOR and involucrin [121-124], independent of the FLG genotype [125], and suppress keratinocyte differentiation via STAT3. Topical treatment with the Janus kinase (JAK) 
inhibitor downregulated STAT3 activation and restored skin barrier function by inducing terminal differentiation in AD animal models [126]. Topical and oral JAK inhibitors, such as tofacitinib, baricitinib and PF-04965842, are in phase II trials for AD [79]. IL-4 and IL-13 stimulate keratinocytes to express TSLP, which serves as a link between barrier defects and Th2 polarization. IL-4-overexpressing transgenic mice develop AD-like lesions. IL-5 attracts eosinophils into chronic AD lesions.

Th2 cytokines IL-4 promote immunoglobulin switching in B cells, resulting in IgE synthesis; induce the expression of adhesion molecules; and recruit various immune cells into skin. With regard to biological agents targeting the Th2 response, several clinical trials have confirmed the therapeutic efficacy and safety of the anti-IL-4 receptor antibody duplimumab [127].

Levels of the Th1 chemokine CCL20 are increased in patients with chronic AD [71]. Among the Th1 cytokines, IL- $1 \alpha$, IL-2 and TGF- $\beta$ were found to be decreased in patients with AD [71], whereas IFN- $\gamma$, IL-12 and granulocyte monocyte-colony stimulating factor were elevated in patients with chronic AD. IFN- $\gamma$ is known to activate keratinocytes and induce their apoptosis. Granulocyte monocyte-colony-stimulating factor is known to prolong the survival of monocytes and induce persistent inflammation. IL-11 and TGF- $\beta 1$ are associated with tissue remodeling in chronic AD [128].

Treg cells are known to suppress both Th1 and Th2 immune responses and to be deficient in AD lesions.

\subsubsection{Th17 Cells}

Th17 cells contribute to the onset of acute AD, although their role in AD is relatively small in psoriasis [12]. Th17 cells produce IL-17 and IL-22, which induce the production of S100 proteins, the AMPs in keratinocytes and various proinflammatory cytokines. IL-17 may have a role in the differentiation of Th2 cells [80]. IL-17 level decreases gradually in chronic AD lesions as Th2 cytokines inhibit IL-17 production. The relative absence of IL-17 in AD lesions may be related to reduced AMP levels and may explain the increased susceptibility to skin infection in patients with AD [129]. IL-17 is responsible for eosinophil and neutrophil-mediated inflammation [130].

The number of Th17 cells and IL-17 expressed in AD lesions and serum is correlated with disease severity [12,131], and this correlation is more prominent in intrinsic AD. A recent study comparing the transcriptome between intrinsic and extrinsic $A D$ indicated that patients with intrinsic $A D$ showed greater Th17 and Th22 immune activation than did those with extrinsic AD [132]. Compared to European and American AD patients, Asian patients presented more epidermal hyperplasia, parakeratosis and stronger Th17 and Th2 activation resembling psoriasis, even in patients with extrinsic AD [133]. However, another study in the European American population found that a number of Th17 cells and IL-17 expression level were reduced in the AD patients with severe symptoms, whereas those of Th2 and Th22 cell subsets were correlated with disease severity [134]. This discrepancy may result from the heterogeneous characteristics of the patients, such as phenotype, disease duration and ethnic differences.

\subsubsection{Th22 T Cells}

The original concept of AD cannot account for the epidermal hyperplasia in patients with chronic AD and has some limitations. Th22 cells produce IL-22, which is responsible for skin barrier impairment and epidermal hyperplasia. Filaggrin expression can be modulated in AD by both the Th2 and Th22 cytokine milieu. Similar to Th2 cytokines, IL-22 compromises the epidermal barrier by suppressing major terminal differentiation proteins [135]. IL-22 increases S100A7, S100A8 and S100A9 gene expression, thus inhibiting epidermal differentiation by enhancing IL-6 secretion, and exerts a proinflammatory effect in AD lesions [114,121]. IL-22 and IL-17 synergistically increase the levels of S100 proteins and AMPs in the epidermis [12,136]. IL-22 secretion can be induced immediately in response to staphylococcal exotoxins and house dust mites and can potentially amplify chronic skin inflammation in patients with AD [137,138]. IL-22 can also stimulate CCL17 production from human keratinocytes and promote the migration of $\mathrm{T}$ cells into the skin [138]. Upregulated 
IL-22 in chronic AD induces matrix metalloproteinase-3, a marker of remodeling; stromelysin-1; platelet-derived growth factor A; and CXCL5 (chemokine, CXC motif, ligand 5) [139]. IL-22 promotes the migration of keratinocytes through matrix metalloproteinases- 1 and -3 and is involved in epidermal hyperplasia [136].

IL-22 binds to its receptors in the form of an IL-22R1/IL-10R2 complex and activates the JAK-STAT signaling pathway via STAT3 activation $[140,141]$. IL-22 expression can be enhanced by the activated Notch signaling pathway without activation of STAT3 [142]. The role of Th22 cells varies depending on the patient's age and disease severity. Infants with AD show only a Th2/Th1 cell imbalance, whereas adults with AD exhibit Th22/Tc22 cell subsets [143]. The numbers of Th22 cells are correlated with disease activity. Moreover, the skin-homing $\mathrm{T}$ cell population of patients with severe AD mostly comprises circulating Th2 and Th22 cells, rather than Th17 cells in European Americans [134]. The role of anti-IL-22 monoclonal antibody is currently being investigated in a phase II trial [80].

\subsubsection{IL-18}

IL-18 is a Th1-like cytokine, which is produced by various cells. Keratinocytes and mast cells produce IL-18 in response to exposure to allergens or pathogens, such as house dust mites and S. aureus [144,145]. Cytotoxic T cells release perforin and granzyme B after the recognition of viral infection in keratinocytes, then subsequently activate pro-IL-18 [146]. Inflammatory dendritic epidermal cells (IDECs) and monocyte-derived DCs also release IL-18 [147]. IL-18 stimulates mast cells to release chymase, which in turn cleaves and activates pro-IL-18. IL-18 stimulates either Th2 or Th1 cytokines based on IL-12. In acute AD lesions, IL-18 stimulates basophils, mast cells and CD4 ${ }^{+} \mathrm{T}$ cells to produce Th2 cytokines without IL-12. In chronic AD lesions, IL-18 stimulates Th1 cells to produce IFN- $\gamma$ with IL-12 [148]. IL-18 contributes to $\mathrm{CD}^{+} \mathrm{T}$ cell- and natural killer T cell-dependent IgE production [146,149]. Corticotrophin-releasing hormone, a skin hypothalamic-pituitary axis molecule, decreases IL-18 expression in monocyte-derived DCs independent of corticotropin-releasing hormone receptors in patients with $\mathrm{AD}$ [150]. This suggests that stress may aggravate AD symptoms by modulating the expression of IL-18.

IL-18 was shown to be a key player in the development of spontaneous AD-like lesions in a mouse model under pathogen-free conditions [151]. Recently, IL-18 levels in the maternal serum and cord blood were found to be a predisposing factor of childhood AD [152]. Elevated levels of serum IL-18 and IL-18 receptors have been suggested as biomarkers of AD severity [146,153], but additional research is required to confirm this suggestion [154,155].

\subsubsection{IL-31}

IL-31, a new Th2 cytokine, is a major pruritogenic inflammatory substance in AD [156]. IL-31 protein and mRNA levels are elevated in AD lesions. Serum levels of IL-31 are proportional to disease severity in patients with AD [157]. IL-31 was found to inhibit epidermal terminal differentiation and enhance proinflammatory cytokine secretion [158,159]. IL-31 can also compromise epidermal barrier function by affecting epidermal terminal differentiation and lipid constituents, and it may inhibit terminal differentiation by downregulating filaggrin and loricrin expression [80,159] IL-31 also decreases ceramide production, increases long-chain FFAs, but decreases ester-linked $\omega$-hydroxy ceramides in stratum corneum lipids [159].

IL-31 functions after binding to a heterodimeric receptor consisting of receptors for IL-31 (IL-31RA) and the oncostatin M receptor $\beta$ complex. IL-31RA is found on keratinocytes, macrophages, eosinophils and nerve fibers in AD and in the neurons of dorsal root ganglia in healthy subjects $[160,161]$. IL-31/IL-31RA complexes activate signal transduction cascades, such as the Janus kinase-STAT (JAK-STAT), mitogen-activated protein kinase and phosphatidyl-inositol 3-kinase pathways [160]. The IL-31/IL-31RA complex stimulates the growth and branching of the nerve in sensory neurons via the STAT3 pathway and not via transient receptor potential cation channel vanilloid subtype 1 channels (TRPV1) [162]. 
A recent study demonstrated the safety and efficacy of a humanized anti-human IL-31RA monoclonal antibody in relieving pruritus in AD [163]. This suggests that the pruritogenic effect of IL-31 is mediated by IL-31RA. Activation of IL-31RA in keratinocytes induces calcium influx and produces more $\beta$-endorphin in STAT3-dependent pathways [164]. Meanwhile, a recent study suggested that the pruritogenic effect of IL-31 was mediated indirectly via keratinocytes and secondary pruritogenic substances, rather than through its receptors on cutaneous nerves [165]. Low doses of IL-31 promote the antimicrobial barrier, and thus, complete inhibition of IL-31 signaling may be undesirable [166].

\subsubsection{B cells}

Although $\mathrm{T}$ cells are key players in the pathogenesis of $\mathrm{AD}, \mathrm{B}$ cells are also found in the dermis of $\mathrm{AD}$ lesions and play significant roles. B cells can present antigens to $\mathrm{CD} 4^{+} \mathrm{T}$ cells and activate $\mathrm{T}$ cells. $\mathrm{B}$ cells interact with T cells via MHC class II molecule/T cell receptor and co-stimulatory molecules, as well as their ligands. Co-stimulatory molecules include CD40 and CD80/CD86 on B cells and their ligands, CD40L and CD28 on T cells. The expression of costimulatory molecule CD86 was reported to be increased on B cells in AD [167]. Th2 cytokine IL-4 promotes immunoglobulin switching in B cells, resulting in IgE synthesis, which then induces the expression of adhesion molecules and recruits various immune cells into skin. B cells also produce chemokines CCL17, CCL22 and IL-16, attracting $\mathrm{T}$ cells to $\mathrm{AD}$ lesions. The levels of IgE are significantly increased in AD patients along with allergic sensitization. IgE contributes to IgE-mediated inflammation by stimulating FceRI-expressing cells, such as mast cells and basophils. Additionally, IgE also contributes to autoallergic inflammation in a certain subset of AD patients. Serum IgE autoantibodies to epidermal self-antigens, such as Homo sapiens antigens 1, had a $38.2 \%$ prevalence in AD patients of autoreactivity, while patients in the control group showed a $6.4 \%$ prevalence [168]. However, the role of $\operatorname{IgE}$ in pathogenesis of AD is not major, and previous attempts to inhibit IgE with omalizumab, respectively, showed heterogeneously different therapeutic efficacy in AD patients [169]. Although B cell-targeting therapy with rituximab (anti-CD20 antibody) showed some improvement in AD patients, it was conducted only in a case series [170].

\subsubsection{Dendritic Cells (DCs)}

DCs play a key role in antigen uptake and presentation and induce a Th2-predominant response. Several types of DCs have been shown to express FceRI in patients with AD [13]. These DCs are easily stimulated and activated by allergens, pathogens, irritants and scratching. Whereas LCs are the predominant DC type in non-lesional AD skin, inflammatory subtype DCs are increased in $\mathrm{AD}$ lesions [171]. IDECs have an increased capacity for antigen presentation and $\mathrm{T}$ cell activation. Topical anti-inflammatory treatment showed a reduced number of inflammatory DC subtypes in AD lesions [172]. On the other hand, the low number of plasmacytoid DCs and reduced amount of type 1 IFN in the lesional epidermis of patients with AD have been suggested to be responsible for the high susceptibility to viral skin infections in these patients [173].

TSLP is abundantly expressed in the epidermis of AD lesions. TSLP induces DCs to express OX40 ligand, which is essential for the differentiation of Th2 cells in the lymph nodes [174]. Activated DCs migrate to the lymph nodes and prime naive $\mathrm{T}$ cell differentiation into Th2 cells in the presence of IL-4 [174]. Expression of the IFN- $\gamma$ receptor on epidermal DCs and their response to IFN- $\gamma$ are attenuated in patients with AD [175]. DCs produce IL-25, which induces Th2 cell differentiation and suppresses filaggrin expression in vitro [12].

Activated epidermal LC and dermal DCs release CCL17 and CCL22, respectively, which in turn recruit and expand Th2 cells [176]. Chemokines (i.e., CCL17, CCL18, CCL19, CXCL9, CXCL10 and CXCL11) expressed by DCs induce further attraction and activation of various inflammatory cells [121]. Epidermal LCs and dermal DCs also induce the differentiation of Th22 cells, and IL- 6 and TNF- $\alpha$ released from DCs have been suggested as contributing factors [177]. 
Plasmacytoid DCs also stimulate naive $\mathrm{T}$ cells to differentiate into Th22 cells in chronic AD lesions. IDECs release the proinflammatory cytokines IL-12 and IL-18, which promote Th1 responses in chronic AD. H4R is expressed by LCs, IDECs, plasmacytoid DCs and 6-sulfoLacnac (slan)-expressing DCs in patients with AD [178,179]. Histamine released from mast cells is relatively rich in $\mathrm{AD}$ lesions, subsequently leading to the activation of $\mathrm{H} 4 \mathrm{R}$-expressing $\mathrm{DCs}$, and contributes to inflammatory processes.

\subsubsection{Chemokines}

Thymus- and activation-regulated chemokine, also known as CCL17, is a key chemokine expressed on vascular endothelium and is involved in the homing of chemokine C-C motif receptor 4 (CCR4)-expressing T cells to the skin. CCL17 promotes the Th2 response via CCR4. The number of CCR4-expressing lymphocytes in serum is correlated with AD severity, the serum IgE level and the blood eosinophil count $[180,181]$. Furthermore, increased CCL17 levels in cord blood are associated with the development of infantile AD [182]. A recent meta-analysis indicated that serum CCL17 is the most reliable biomarker identified to date [154]. Similar to CCL17, macrophage-derived chemokine, also known as CCL22, is a chemoattractant for CCR4-expressing T cells. The Th2 chemokines CCL17 and CCL22 are mainly produced by LCs [183]. The levels of CCL17 and CCL22 may reflect the degree of skin barrier impairment. CCL17 and CCL22 induce the skin homing of T cells into AD lesions, and H4R antagonist inhibits CCL17 and CCL22 chemokine production by LCs in patients with AD [184]. Cutaneous T cell-attracting chemokine, also known as CCL27, is produced by keratinocytes and attracts CCR10-expressing Th22 cells into the skin. CCR6 is expressed in Th17 cells and facilitates their migration to the skin depending on the ligand CCL20 [185].

IFN- $\gamma$, monocyte chemotactic protein-4, eotaxin and RANTES secreted from keratinocytes after stimulation with Th1 cytokines facilitate the migration of macrophages, eosinophils and Th1 cells into chronic AD lesions [10]. CCL26 (eotaxin-3), which is essential to eosinophil recruitment into lesional epidermis, is enhanced by IL-4 and IL-13 [186]. IL-4 also stimulates dermal fibroblasts to express CCL11 (eotaxin-1) in AD lesions [187]. CCL11 was also detected on the lymphocytes, macrophages and eosinophils in AD lesions [188]. RANTES/CCL5 is a potent chemoattractant for eosinophils. CCL11, CCL5 and CCL26 bind to CCR3 expressed on eosinophils and activate these cells [189]. Fractalkine (CX3CL1) is expressed on the vascular endothelium and traffics leukocytes into AD lesions. Serum CX3CL1 levels were correlated with disease severity in pediatric AD patients [190,191].

\subsubsection{Mast Cells}

The role of mast cells in the pathogenesis of AD is not completely understood. Increased numbers of mast cells are seen in AD lesions, especially in the chronic state. After exposure to allergens, FceRI and IgE binding induce mast cell degranulation and cause acute symptoms by releasing preformed mediators, such as histamine, heparin, serotonin, prostaglandins, leukotrienes, major basic protein and platelet-activating factor. Patients with distinct STAT3 mutations present enhanced STAT3 signaling in mast cells and accelerated degranulation [192]. Histamine and tryptase released by mast cells evoke scratching behavior and secondary barrier disruption. Mast cells are involved in the pathogenesis of AD not only by releasing inflammatory mediators, but also by directly regulating the recruitment and action of various inflammatory cells. Mast cells regulate the differentiation, activation and migration of $\mathrm{T}$ cells by inducing the expression of chemokines and adhesion molecules on endothelial cells [193]. Prostaglandin D2, a mast cell mediator, downregulates IL-12 production by DCs, which leads to a Th2-polarized immune response [194]. Mast cells are among the sources of IL-4 and IL-13 production [195]. Overexpression of TSLP in AD lesions can further activate mast cells to generate more Th2 cytokines [196]. Ligands for CD40 on mast cells interact with CD40 on the surface of B cells and stimulate B cell development and IgE synthesis in the presence of IL-4 [197]. Histamine and TNF are known to facilitate the migration of DCs into lymph nodes $[198,199]$. Chemokines derived from 
mast cells attract eosinophils and type 2 innate lymphoid cells [10,200]. IL-33 can induce mast cells to produce proinflammatory cytokines and chemokines [201].

Mast cells not only serve as key inflammatory mediators, but also play a protective role in the development of AD. A recent study indicated that mast cell-knockout mice showed incomplete epidermal differentiation with decreased EDC gene expression and easily developed severe AD-like skin inflammation [202].

\subsubsection{Eosinophils and Basophils}

Eosinophils are increased in number in both the serum and lesions of patients with AD, and they contribute to the pathogenesis of AD. Tissue eosinophilia is reportedly correlated with the severity of AD [203]. The Th2 cytokines IL-4, IL-5 and IL-13 play important roles in the development, survival, recruitment and function of eosinophils. Various inflammatory mediators are released during degranulation of eosinophils, including eosinophil cationic protein, eosinophil-derived neurotoxin and major basic protein. Eosinophil cationic protein and eosinophil-derived neurotoxin exhibit RNase activity and neurotoxicity. Eosinophil-derived neurotoxin induces maturation and activation of DCs by the TLR2-MyD88 signaling pathway and increases Th2 responses [204]. Major basic protein can downregulate the integrity of lipid bilayers [205]. Eosinophils constitutively express IL-31RA and release various proinflammatory cytokines and chemokines, such as IL-1 $\beta$, IL-6, IL-31, CXCL1, CXCL8, CCL2, CCL18 and CCL26, in response to IL-31 [206-208]. IL-31 can prolong the survival of eosinophils by activating ERK signaling [207].

Similar to mast cells, basophils express FceRI and degranulate after binding of IgE to FceRI. Basophils play a role in producing Th2 cytokines in response to IL-18, as well as in promoting type 2 innate lymphoid cell (ILC2) recruitment and proliferation by releasing IL-4 in mouse AD models [209]. Basophils express ST2, a receptor for IL-33, and are activated by IL-33 [201]. Basophils express PAMPs, such as NOD2 and TLR2, and play a role in innate immune defense. S. aureus exacerbates AD symptoms by binding to NOD2 and TLR2 and by activating basophils and eosinophils in AD mouse models [210]. Recently, NOD2 expression by basophils in AD patients was found to be downregulated, which may explain the ineffective host defense to S. aureus in AD [211].

\subsubsection{Innate Lymphoid Cells}

ILCs are effector cells of innate immunity that are derived from a common lymphoid progenitor, but they do not express cell lineage markers for myeloid and DCs. ILC2s have been detected in the skin, peripheral blood, gastrointestinal tract and airways. ILCs can be divided into three groups based on predominant cytokine type. ILC1s produce Th1 cytokines, including IFN- $\gamma$; ILC2s produce Th2 cytokines, including IL-5 and IL-13; and ILC3s produce Th17 cytokines, such as IL-17 and IL-22 [212].

The transcription factor RAR-related orphan receptor alpha and GATA-3 induce differentiation of ILC2s in the presence of IL-25 and IL-33 [213]. Aberrant ILC2 function may contribute to allergic inflammation, such as AD [214,215]. ILC2s express CLA and CCR4, infiltrate the skin after allergen exposure and produce Th2 cytokines. Filaggrin deficiency is associated with increased ILC2 infiltration into the skin in both mice and patients with $\mathrm{AD}$ [216]. In response to barrier disruption, keratinocytes produce IL-25, IL-33 and TSLP. ILC2s express IL-25R, ST2 and TSLPR and are activated by IL-25, IL-33 and TSLP to produce IL-5 and IL-13. E-cadherin, the adhesion molecule between keratinocytes, is known to suppress the activation of skin ILC2s, possibly via ligation through killer cell lectin-like receptor G1 on human ILC2s. E-cadherin expression in keratinocytes is reduced due to loss of the skin barrier in AD lesions [217]. Subsequently, ILC2 may contribute to the production of high levels of the Th2 cytokines IL- 5 and IL-13 in the absence of the inhibitory E-cadherin signal [213,218]. ILC2 cells produce IL-9, which attracts mast cells into the skin and augments their activation [214]. ILC2s are also activated and migrate in response to prostaglandin D2 [219]. Moreover, depletion of ILC2s blocked the skin homing of Th2 cells by inhibiting the production of the Th2 chemokine CCL17 in DCs in mouse 
models of AD $[214,215,220]$. ILC2s stimulated with IL-2 alone were sufficient to drive Th2 responses and AD-like inflammation without the influence of adaptive immunity in mouse models [221,222].

\subsection{Signal Pathways}

\subsubsection{GATA-3}

GATA-3 is a key regulator of $\mathrm{CD} 4^{+} \mathrm{T}$ cell development, homeostasis, activation and proliferation. GATA-3 is known as a transcription factor that drives the differentiation of Th2 cells, stimulates the secretion of Th2 cytokines from Th2 cells and inhibits the development of B cells. GATA-3 plays a critical role in the differentiation of Th2 cells and is involved in the Th2 cytokine-mediated signaling network in AD. Th2 differentiation could be induced by both STAT6-dependent and STAT6-independent pathways. Acting in the downstream pathway of STAT6, GATA-3 activates IL-4, IL-5 and IL-13, but inhibits the expression of IFN- $\gamma$ via STAT6-dependent pathways. GATA3 activates the common cellular signaling pathway including c-Jun N-terminal kinases, protein kinase C, JAK-STAT6 and nuclear factor kappa-light-chain-enhancer of activated B cells (NF- $k B$ ) in T cells [223]. GATA-3 has a positive-feedback loop that further activates GATA-3 and reinforces Th2 differentiation. In AD lesions, GATA-3 signaling is inhibited by T-bet, which is the Th1 transcription factor. By downregulating STAT-4, GATA-3 enabled Th2-predominant cytokine profiles to be maintained. GATA3 is regulated by diverse upstream signals, including IL-4R/STAT6, IL-2 receptor/STAT5, p38 MAP kinase, T cell receptor and Notch. Notch signaling or IL-2 receptor signaling could induce Th2 differentiation through GATA-3 in the STAT6-independent pathway [224]. Furthermore, AD patients showed a weak $\mathrm{T}$ cell receptor signaling, which enhances Th2 immunity and IgE production in order to compensate a weak $\mathrm{T}$ cell receptor signaling [225]. 4-hydroxy-3-methoxycinnamaldehyde downregulated T cell proliferation and differentiation into Th1 and Th2 cells by inhibiting T-bet and GATA3, respectively, and could ameliorate the symptoms of AD in mice models [226]. Recently, SB011, a topical DNAzyme that cleaves GATA-3, has been developed and is in a phase II clinical trial [79].

GATA-3 is also involved in Th9 differentiation, but inhibits Th1 and Th17 differentiation. GATA-3 regulates the function of Tregs by inducing forkhead box P3 (Foxp3) expression. As mentioned above, GATA-3 plays important roles in the generation and function of ILCs [223]. A recent GWAS of severe AD found new loci including candidate genes that may contribute to the defects in GATA-3 and STAT6 $[59,227,228]$.

B cell activation is initiated by the engagement of B cell receptor and co-receptor, which leads to the change in the gene expression, as well as common cellular signaling, such as protein kinase $C, N F-k B$ and c-fos. Information regarding unique abnormalities of $B$ cell signaling in the AD pathogenesis is not well known. In order to establish $B$ cell generation and maturation, CD40-CD40L interaction between $B$ cells and $T$ cells is essential, and $B$ cell activation is parallel to $T$ cell activation in a thymus-dependent manner [229].

\subsubsection{Notch Signaling}

The lesional epidermis of patients with AD exhibits markedly suppressed expression of Notch and its receptors, and reduced Notch expression in the lesions was shown to be normalized after successful treatment [230]. Impaired Notch signaling adversely influences epidermal terminal differentiation by affecting filaggrin, involucrin and transglutaminase- 3 activity, resulting in incomplete $\mathrm{CE}$ and barrier formation. Suppressed Notch signaling downregulates the expression of aquaporin 3 and claudin-1, thus resulting in barrier dysfunction and increased transepidermal water loss [230,231]. Notch inhibits TLR-activated innate immunity by a negative feedback mechanism [232]. Thus, deficiency in Notch signaling may result in persistent activation of macrophages and DCs as observed in AD. The IFNG has recently been found as a target of Notch1 [233]. Compromised Notch signaling may thus explain the increased susceptibility to viral skin infection in AD through diminished IFN- $\gamma$ production. Notch1 is an inhibitor of a transcription factor called activator protein-1, which is upregulated in the AD-affected 
epidermis and promotes Th2 cytokine production. The absence of Notch-mediated downregulation of activator protein-1 results in upregulation of the levels of IL-31 and may aggravate IL-31-mediated pruritus in AD [231]. Notch deficiency induces keratinocytes to secrete TSLP, which has recently been shown to stimulate cutaneous sensory neurons to promote itch [234]. Notch-knockout mice exhibit AD-like skin inflammation. In the presence of TGF- $\beta$, Notch1 regulates Foxp3 expression, which is important in the differentiation of Tregs.

\section{Conclusions}

Patients with AD have impaired skin integrity and show elevated susceptibility to allergens and pathogens, which activate innate and adaptive immune responses. AD is characterized as a Th2/Th22-predominant inflammatory disease, but Th1 and Th17 responses modulate the development and progression of $\mathrm{AD}$. Although T cells play key roles in the inflammation seen in $\mathrm{AD}$, keratinocytes, DCs, B cells, mast cells, eosinophils, basophils and ILC2s act together through various cytokines and chemokines (Figure 1).

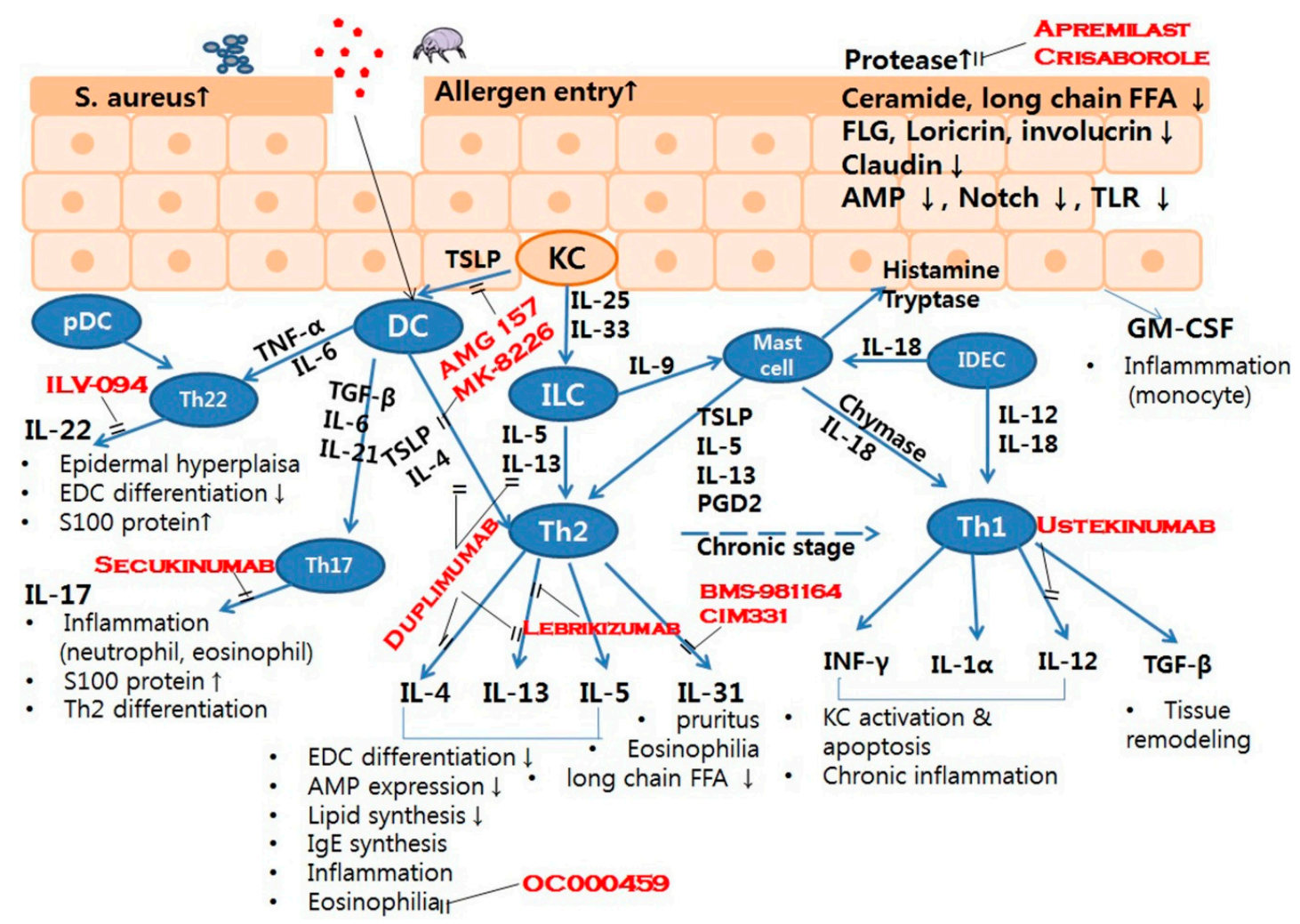

Figure 1. Barrier and immune network in the pathogenesis of atopic dermatitis. Red words: drug name; Dotted line (chronic stage): disease progression; Line: secretion.

Therapeutics include: duplimumab, anti-IL-4Ra monoclonal antibodies (mAb); lebrikizumab, anti-IL-13 mAb; ILV-094, anti-IL-22 mAb; BMS-981164, anti-IL-31 mAb; CIM331, anti-IL-31R mAb; AMG 157, anti-TSLP mAb; MK-8226 anti-TSLPR mAb; ustekinumab, anti-IL-12/IL-23 mAb; secukinumab, anti-IL-17 mAb; OC000459, chemoattractant receptor-homologous molecule expressed on Th2 cell antagonist.

IL-4, -5, -13 and -31 drive Th2 inflammatory responses, but also inhibit epidermal terminal differentiation and lipid barrier formation and, thus, disrupt barrier functions. This is consistent with the "outside-in" and "inside-out" hypotheses [235]. Complex interactions between genes and environmental factors have been revealed, and further studies will reveal how environmental changes can regulate the development and triggering of AD. Current therapeutic options are often 
unsatisfactory to the refractory $\mathrm{AD}$ patients. Taken together, these data extend our knowledge of newly-found genes and signaling molecules as possible therapeutic targets for AD.

Acknowledgments: This work was supported by the Basic Science Research program and Creative Materials Discovery Program through the National Research Foundation of Korea (NRF), which is funded by the Ministry of Education, Science and Technology and the Ministry of Science, ICT and Future Planning (2015R1C1A2A01055073, 2016M3D1A1021387). We also thank Yujin Jung for help in preparation of the revised paper.

Author Contributions: Jung Eun Kim wrote and revised the manuscript. Jong Sic Kim assisted with the writing and revision of the manuscript. Dae Ho Cho and Hyun Jeong Park designed the review and assisted with the writing and revision of the manuscript.

Conflicts of Interest: The authors declare no conflict of interest.

\section{Abbreviations}

\begin{tabular}{|c|c|}
\hline $\mathrm{AD}$ & Atopic dermatitis \\
\hline AMPs & Antimicrobial peptides \\
\hline CARD & Caspase recruitment domain \\
\hline CCL & $\mathrm{C}-\mathrm{C}$ motif chemokine ligand \\
\hline CCR & C-C motif chemokine receptor \\
\hline CLDN1 & Claudin-1 \\
\hline $\mathrm{CE}$ & Cornified envelope \\
\hline CXCL & $\mathrm{C}-\mathrm{X}-\mathrm{C}$ motif chemokine ligand \\
\hline DCs & Dendritic cells \\
\hline EDC & Epidermal differentiation complex \\
\hline ERK & Extracellular signal-regulated kinase \\
\hline FceRI & High affinity IgE receptor \\
\hline FFA & Free fatty acid \\
\hline FLG & Filaggrin gene \\
\hline Foxp3 & Forkhead box P3 \\
\hline GATA-3 & GATA-binding protein 3 \\
\hline GWAS & Genome-wide association study \\
\hline hBD & Human $\beta$-defensin \\
\hline HRH4 & Histamine receptor $\mathrm{H} 4$ \\
\hline IDECs & Inflammatory dendritic epidermal cells \\
\hline IFNG & $I F N-\gamma$ gene \\
\hline ILCs & Innate lymphoid cells \\
\hline IL18RAP & Interleukin 18 receptor accessory protein \\
\hline JAK & Janus kinase \\
\hline JNK & c-Jun $N$-terminal kinase \\
\hline LCs & Langerhans cells \\
\hline LEKTI & Lymphoepithelial Kazal-type trypsin inhibitor \\
\hline $\mathrm{mAb}$ & Monoclonal antibodies \\
\hline $\operatorname{miR}$ & MicroRNA \\
\hline MMP & Matrix metalloproteinase \\
\hline NALP & NACHT, LRR and PYD domain-containing protein \\
\hline $\mathrm{NF}-\mathrm{kB}$ & Nuclear factor $\mathrm{K}$-light-chain-enhancer of activated B cells \\
\hline NOD & Nucleotide-binding oligomerization domain receptors \\
\hline PAR2 & Protease-activated type 2 receptor \\
\hline PDE4 & Phosphodiesterase 4 \\
\hline RANTES & Regulated on activation, normal $\mathrm{T}$ cell expressed and secreted \\
\hline SC & Stratum corneum \\
\hline SNP & Single nucleotide polymorphism \\
\hline SP & Serine protease \\
\hline STAT & Signal transducer and activator of transcription \\
\hline Th & T helper \\
\hline TLR & Toll-like receptor \\
\hline TMEM79 & Transmembrane protein 79 \\
\hline Treg & Regulatory T cell \\
\hline TSLP & Thymic stromal lymphopoietin \\
\hline SPINK5 & Serine protease inhibitor Kazal-type 5 \\
\hline SPRR3 & Small proline-rich protein 3 \\
\hline
\end{tabular}




\section{References}

1. Odhiambo, J.A.; Williams, H.C.; Clayton, T.O.; Robertson, C.F.; Asher, M.I. Global variations in prevalence of eczema symptoms in children from isaac phase three. J. Allergy Clin. Immunol. 2009, 124, 1251-1258. [CrossRef] [PubMed]

2. Barnes, K.C. An update on the genetics of atopic dermatitis: Scratching the surface in 2009. J. Allergy Clin. Immunol. 2010, 125, 16-29. [CrossRef] [PubMed]

3. Tay, Y.K.; Kong, K.H.; Khoo, L.; Goh, C.L.; Giam, Y.C. The prevalence and descriptive epidemiology of atopic dermatitis in singapore school children. Br. J. Dermatol. 2002, 146, 101-106. [CrossRef] [PubMed]

4. Tokura, Y. Extrinsic and intrinsic types of atopic dermatitis. J. Dermatol. Sci. 2010, 58, 1-7. [CrossRef] [PubMed]

5. Katsarou, A.; Armenaka, M. Atopic dermatitis in older patients: Particular points. J. Eur. Acad. Dermatol. Venereol. 2011, 25, 12-18. [CrossRef] [PubMed]

6. Bantz, S.K.; Zhu, Z.; Zheng, T. The atopic march: Progression from atopic dermatitis to allergic rhinitis and asthma. J. Clin. Cell. Immunol. 2014, 5. [CrossRef]

7. Andersen, R.M.; Thyssen, J.P.; Maibach, H.I. Qualitative vs. Quantitative atopic dermatitis criteria-In historical and present perspectives. J. Eur. Acad. Dermatol. Venereol. 2016, 30, 604-618. [CrossRef] [PubMed]

8. Oranje, A.P.; Glazenburg, E.J.; Wolkerstorfer, A.; de Waard-van der Spek, F.B. Practical issues on interpretation of scoring atopic dermatitis: The scorad index, objective scorad and the three-item severity score. Br. J. Dermatol. 2007, 157, 645-648. [CrossRef] [PubMed]

9. Kim, J.E.; Kim, H.J.; Lew, B.L.; Lee, K.H.; Hong, S.P.; Jang, Y.H.; Park, K.Y.; Seo, S.J.; Bae, J.M.; Choi, E.H.; et al. Consensus guidelines for the treatment of atopic dermatitis in korea (Part II): Systemic treatment. Ann. Dermatol. 2015, 27, 578-592. [CrossRef] [PubMed]

10. Mu, Z.; Zhao, Y.; Liu, X.; Chang, C.; Zhang, J. Molecular biology of atopic dermatitis. Clin. Rev. Allergy Immunol. 2014, 47, 193-218. [CrossRef] [PubMed]

11. Ghosh, D.; Ding, L.; Sivaprasad, U.; Geh, E.; Biagini Myers, J.; Bernstein, J.A.; Khurana Hershey, G.K.; Mersha, T.B. Multiple transcriptome data analysis reveals biologically relevant atopic dermatitis signature genes and pathways. PLoS ONE 2015, 10, e0144316. [CrossRef] [PubMed]

12. Czarnowicki, T.; Krueger, J.G.; Guttman-Yassky, E. Skin barrier and immune dysregulation in atopic dermatitis: An evolving story with important clinical implications. J. Allergy Clin. Immunol. Pract. 2014, 2, 371-379. [CrossRef] [PubMed]

13. Boguniewicz, M.; Leung, D.Y. Atopic dermatitis: A disease of altered skin barrier and immune dysregulation. Immunol. Rev. 2011, 242, 233-246. [CrossRef] [PubMed]

14. Palmer, C.N.; Irvine, A.D.; Terron-Kwiatkowski, A.; Zhao, Y.; Liao, H.; Lee, S.P.; Goudie, D.R.; Sandilands, A.; Campbell, L.E.; Smith, F.J.; et al. Common loss-of-function variants of the epidermal barrier protein filaggrin are a major predisposing factor for atopic dermatitis. Nat. Genet. 2006, 38, 441-446. [CrossRef] [PubMed]

15. Leung, D.Y. Our evolving understanding of the functional role of filaggrin in atopic dermatitis. J. Allergy Clin. Immunol. 2009, 124, 494-495. [CrossRef] [PubMed]

16. Henderson, J.; Northstone, K.; Lee, S.P.; Liao, H.; Zhao, Y.; Pembrey, M.; Mukhopadhyay, S.; Smith, G.D.; Palmer, C.N.; McLean, W.H.; et al. The burden of disease associated with filaggrin mutations: A population-based, longitudinal birth cohort study. J. Allergy Clin. Immunol. 2008, 121, 872-877. [CrossRef] [PubMed]

17. Brown, S.J.; McLean, W.H. Eczema genetics: Current state of knowledge and future goals. J. Investig. Dermatol. 2009, 129, 543-552. [CrossRef] [PubMed]

18. Li, M.; Liu, Q.; Liu, J.; Cheng, R.; Zhang, H.; Xue, H.; Bao, Y.; Yao, Z. Mutations analysis in filaggrin gene in Northern China patients with atopic dermatitis. J. Eur. Acad. Dermatol. Venereol. 2013, 27, 169-174. [CrossRef] [PubMed]

19. Chen, H.; Common, J.E.; Haines, R.L.; Balakrishnan, A.; Brown, S.J.; Goh, C.S.; Cordell, H.J.; Sandilands, A.; Campbell, L.E.; Kroboth, K.; et al. Wide spectrum of filaggrin-null mutations in atopic dermatitis highlights differences between Singaporean Chinese and European populations. Br. J. Dermatol. 2011, 165, 106-114. [CrossRef] [PubMed] 
20. Li, K.; Seok, J.; Park, K.Y.; Yoon, Y.; Kim, K.H.; Seo, S.J. Copy-number variation of the filaggrin in Korean patients with atopic dermatitis: What really matters, "number" or "variation"? Br. J. Dermatol. 2016, 174, 1098-1100. [CrossRef] [PubMed]

21. Brown, S.J.; Kroboth, K.; Sandilands, A.; Campbell, L.E.; Pohler, E.; Kezic, S.; Cordell, H.J.; McLean, W.H.; Irvine, A.D. Intragenic copy number variation within filaggrin contributes to the risk of atopic dermatitis with a dose-dependent effect. J. Investig. Dermatol. 2012, 132, 98-104. [CrossRef] [PubMed]

22. Kezic, S.; O’Regan, G.M.; Yau, N.; Sandilands, A.; Chen, H.; Campbell, L.E.; Kroboth, K.; Watson, R.; Rowland, M.; McLean, W.H.; et al. Levels of filaggrin degradation products are influenced by both filaggrin genotype and atopic dermatitis severity. Allergy 2011, 66, 934-940. [CrossRef] [PubMed]

23. Margolis, D.J.; Gupta, J.; Apter, A.J.; Ganguly, T.; Hoffstad, O.; Papadopoulos, M.; Rebbeck, T.R.; Mitra, N. Filaggrin-2 variation is associated with more persistent atopic dermatitis in African American subjects. J. Allergy Clin. Immunol. 2014, 133, 784-789. [CrossRef] [PubMed]

24. Weidinger, S.; Willis-Owen, S.A.; Kamatani, Y.; Baurecht, H.; Morar, N.; Liang, L.; Edser, P.; Street, T.; Rodriguez, E.; O'Regan, G.M.; et al. A genome-wide association study of atopic dermatitis identifies loci with overlapping effects on asthma and psoriasis. Hum. Mol. Genet. 2013, 22, 4841-4856. [CrossRef] [PubMed]

25. Marenholz, I.; Rivera, V.A.; Esparza-Gordillo, J.; Bauerfeind, A.; Lee-Kirsch, M.A.; Ciechanowicz, A.; Kurek, M.; Piskackova, T.; Macek, M.; Lee, Y.A. Association screening in the epidermal differentiation complex (EDC) identifies an SPRR3 repeat number variant as a risk factor for eczema. J. Investig. Dermatol. 2011, 131, 1644-1649. [CrossRef] [PubMed]

26. Kelsell, D.P.; Byrne, C. Snping at the epidermal barrier. J. Investig. Dermatol. 2011, 131, 1593-1595. [CrossRef] [PubMed]

27. Saunders, S.P.; Goh, C.S.; Brown, S.J.; Palmer, C.N.; Porter, R.M.; Cole, C.; Campbell, L.E.; Gierlinski, M.; Barton, G.J.; Schneider, G.; et al. Tmem79/matt is the matted mouse gene and is a predisposing gene for atopic dermatitis in human subjects. J. Allergy Clin. Immunol. 2013, 132, 1121-1129. [CrossRef] [PubMed]

28. Elias, P.M.; Wakefield, J.S. Mechanisms of abnormal lamellar body secretion and the dysfunctional skin barrier in patients with atopic dermatitis. J. Allergy Clin. Immunol. 2014, 134, 781-791. [CrossRef] [PubMed]

29. Sasaki, T.; Shiohama, A.; Kubo, A.; Kawasaki, H.; Ishida-Yamamoto, A.; Yamada, T.; Hachiya, T.; Shimizu, A.; Okano, H.; Kudoh, J.; et al. A homozygous nonsense mutation in the gene for TMEM79, a component for the lamellar granule secretory system, produces spontaneous eczema in an experimental model of atopic dermatitis. J. Allergy Clin. Immunol. 2013, 132, 1111-1120. [CrossRef] [PubMed]

30. Lan, C.C.; Tu, H.P.; Wu, C.S.; Ko, Y.C.; Yu, H.S.; Lu, Y.W.; Li, W.C.; Chen, Y.C.; Chen, G.S. Distinct spink5 and IL-31 polymorphisms are associated with atopic eczema and non-atopic hand dermatitis in taiwanese nursing population. Exp. Dermatol. 2011, 20, 975-979. [CrossRef] [PubMed]

31. Fortugno, P.; Furio, L.; Teson, M.; Berretti, M.; El Hachem, M.; Zambruno, G.; Hovnanian, A.; D’Alessio, M. The 420K LEKTI variant alters LEKTI proteolytic activation and results in protease deregulation: Implications for atopic dermatitis. Hum. Mol. Genet. 2012, 21, 4187-4200. [CrossRef] [PubMed]

32. De Benedetto, A.; Rafaels, N.M.; McGirt, L.Y.; Ivanov, A.I.; Georas, S.N.; Cheadle, C.; Berger, A.E.; Zhang, K.; Vidyasagar, S.; Yoshida, T.; et al. Tight junction defects in patients with atopic dermatitis. J. Allergy Clin. Immunol. 2011, 127, 773-786. [CrossRef] [PubMed]

33. Yu, H.S.; Kang, M.J.; Kwon, J.W.; Lee, S.Y.; Lee, E.; Yang, S.I.; Jung, Y.H.; Hong, K.; Kim, Y.J.; Lee, S.H.; et al. Claudin-1 polymorphism modifies the effect of mold exposure on the development of atopic dermatitis and production of IgE. J. Allergy Clin. Immunol. 2015, 135, 827-830. [CrossRef] [PubMed]

34. Paternoster, L.; Standl, M.; Chen, C.M.; Ramasamy, A.; Bonnelykke, K.; Duijts, L.; Ferreira, M.A.; Alves, A.C.; Thyssen, J.P.; Albrecht, E.; et al. Meta-analysis of genome-wide association studies identifies three new risk loci for atopic dermatitis. Nat. Genet. 2012, 44, 187-192. [CrossRef] [PubMed]

35. Hirota, T.; Takahashi, A.; Kubo, M.; Tsunoda, T.; Tomita, K.; Sakashita, M.; Yamada, T.; Fujieda, S.; Tanaka, S.; Doi, S.; et al. Genome-wide association study identifies eight new susceptibility loci for atopic dermatitis in the japanese population. Nat. Genet. 2012, 44, 1222-1226. [CrossRef] [PubMed]

36. Suarez-Farinas, M.; Ungar, B.; Correa da Rosa, J.; Ewald, D.A.; Rozenblit, M.; Gonzalez, J.; Xu, H.; Zheng, X.; Peng, X.; Estrada, Y.D.; et al. RNA sequencing atopic dermatitis transcriptome profiling provides insights into novel disease mechanisms with potential therapeutic implications. J. Allergy Clin. Immunol. 2015, 135, 1218-1227. [CrossRef] [PubMed] 
37. Esaki, H.; Ewald, D.A.; Ungar, B.; Rozenblit, M.; Zheng, X.; Xu, H.; Estrada, Y.D.; Peng, X.; Mitsui, H.; Litman, T.; et al. Identification of novel immune and barrier genes in atopic dermatitis by means of laser capture microdissection. J. Allergy Clin. Immunol. 2015, 135, 153-163. [CrossRef] [PubMed]

38. Tamari, M.; Hirota, T. Genome-wide association studies of atopic dermatitis. J. Dermatol. 2014, 41, $213-220$. [CrossRef] [PubMed]

39. Paternoster, L.; Standl, M.; Waage, J.; Baurecht, H.; Hotze, M.; Strachan, D.P.; Curtin, J.A.; Bønnelykke, K.; Tian, C.; Takahashi, A.; et al. Multi-ancestry genome-wide association study of 21,000 cases and 95,000 controls identifies new risk loci for atopic dermatitis. Nat. Genet. 2015, 47, 1449-1456. [CrossRef] [PubMed]

40. Ahmad-Nejad, P.; Mrabet-Dahbi, S.; Breuer, K.; Klotz, M.; Werfel, T.; Herz, U.; Heeg, K.; Neumaier, M.; Renz, H. The toll-like receptor 2 R753Q polymorphism defines a subgroup of patients with atopic dermatitis having severe phenotype. J. Allergy Clin. Immunol. 2004, 113, 565-567. [CrossRef] [PubMed]

41. Oh, D.Y.; Schumann, R.R.; Hamann, L.; Neumann, K.; Worm, M.; Heine, G. Association of the toll-like receptor 2 A-16934T promoter polymorphism with severe atopic dermatitis. Allergy 2009, 64, 1608-1615. [CrossRef] [PubMed]

42. Potaczek, D.P.; Nastalek, M.; Okumura, K.; Wojas-Pelc, A.; Undas, A.; Nishiyama, C. An association of TLR2-16934A>T polymorphism and severity/phenotype of atopic dermatitis. J. Eur. Acad. Dermatol. Venereol. 2011, 25, 715-721. [CrossRef] [PubMed]

43. Salpietro, C.; Rigoli, L.; Miraglia Del Giudice, M.; Cuppari, C.; Di Bella, C.; Salpietro, A.; Maiello, N.; La Rosa, M.; Marseglia, G.L.; Leonardi, S.; et al. TLR2 and TLR4 gene polymorphisms and atopic dermatitis in Italian children: A multicenter study. Int. J. Immunopathol. Pharmacol. 2011, 24, 33-40. [PubMed]

44. Levchenko, L.; Izmailova, O.V.; Shlykova, O.A.; Kaidashev, I.P. Polymorphism 896A/G of TLR4 gene rather than 1196C/T and 2258G/A of TLR2 gene determines severe and complicated course of atopic dermatitis in children. Tsitol. Genet. 2013, 47, 46-53. [PubMed]

45. Novak, N.; Yu, C.F.; Bussmann, C.; Maintz, L.; Peng, W.M.; Hart, J.; Hagemann, T.; Diaz-Lacava, A.; Baurecht, H.J.; Klopp, N.; et al. Putative association of a TLR9 promoter polymorphism with atopic eczema. Allergy 2007, 62, 766-772. [CrossRef] [PubMed]

46. Macaluso, F.; Nothnagel, M.; Parwez, Q.; Petrasch-Parwez, E.; Bechara, F.G.; Epplen, J.T.; Hoffjan, S. Polymorphisms in NACHT-LRR (NLR) genes in atopic dermatitis. Exp. Dermatol. 2007, 16, 692-698. [CrossRef] [PubMed]

47. Kim, E.; Lee, J.E.; Namkung, J.H.; Kim, P.S.; Kim, S.; Shin, E.S.; Cho, E.Y.; Yang, J.M. Single nucleotide polymorphisms and the haplotype in the DEFB1 gene are associated with atopic dermatitis in a Korean population. J. Dermatol. Sci. 2009, 54, 25-30. [CrossRef] [PubMed]

48. Gao, P.S.; Rafaels, N.M.; Mu, D.; Hand, T.; Murray, T.; Boguniewicz, M.; Hata, T.; Schneider, L.; Hanifin, J.M.; Gallo, R.L.; et al. Genetic variants in thymic stromal lymphopoietin are associated with atopic dermatitis and eczema herpeticum. J. Allergy Clin. Immunol. 2010, 125, 1403-1407. [CrossRef] [PubMed]

49. Margolis, D.J.; Kim, B.; Apter, A.J.; Gupta, J.; Hoffstad, O.; Papadopoulos, M.; Mitra, N. Thymic stromal lymphopoietin variation, filaggrin loss of function, and the persistence of atopic dermatitis. JAMA Dermatol. 2014, 150, 254-259. [CrossRef] [PubMed]

50. Novak, N.; Kruse, S.; Potreck, J.; Maintz, L.; Jenneck, C.; Weidinger, S.; Fimmers, R.; Bieber, T. Single nucleotide polymorphisms of the IL18 gene are associated with atopic eczema. J. Allergy Clin. Immunol. 2005, 115, 828-833. [CrossRef] [PubMed]

51. Cheng, D.; Hao, Y.; Zhou, W.; Ma, Y. The relationship between interleukin-18 polymorphisms and allergic disease: A meta-analysis. BioMed Res. Int. 2014, 2014, 290687. [CrossRef] [PubMed]

52. Gao, L.; Bin, L.; Rafaels, N.M.; Huang, L.; Potee, J.; Ruczinski, I.; Beaty, T.H.; Paller, A.S.; Schneider, L.C.; Gallo, R.; et al. Targeted deep sequencing identifies rare loss-of-function variants in IFNGR1 for risk of atopic dermatitis complicated by eczema herpeticum. J. Allergy Clin. Immunol. 2015, 136, 1591-1600. [CrossRef] [PubMed]

53. Namkung, J.H.; Lee, J.E.; Kim, E.; Kim, S.; Kim, S.; Shin, E.S.; Cho, E.Y.; Yang, J.M. Association of single nucleotide polymorphisms in the IL-12 (IL-12a and b) and IL-12 receptor (IL-12r $\beta 1$ and $\beta 2$ ) genes and gene-gene interactions with atopic dermatitis in koreans. J. Dermatol. Sci. 2010, 57, 199-206. [CrossRef] [PubMed] 
54. Wang, S.S.; Hon, K.L.; Kong, A.P.; Tang, M.F.; Sy, H.Y.; Chan, J.C.; Leung, T.F. Eczema phenotypes are associated with multiple vitamin d pathway genes in chinese children. Allergy 2014, 69, 118-124. [CrossRef] [PubMed]

55. Hallau, J.; Hamann, L.; Schumann, R.R.; Worm, M.; Heine, G. A promoter polymorphism of the vitamin D metabolism gene CYP24A1 is associated with severe atopic dermatitis in adults. Acta Derm. Venereol. 2016, 96, 169-172. [CrossRef] [PubMed]

56. Heine, G.; Hoefer, N.; Franke, A.; Nothling, U.; Schumann, R.R.; Hamann, L.; Worm, M. Association of vitamin d receptor gene polymorphisms with severe atopic dermatitis in adults. Br. J. Dermatol. 2013, 168, 855-858. [CrossRef] [PubMed]

57. Tamura, K.; Arakawa, H.; Suzuki, M.; Kobayashi, Y.; Mochizuki, H.; Kato, M.; Tokuyama, K.; Morikawa, A. Novel dinucleotide repeat polymorphism in the first exon of the STAT- 6 gene is associated with allergic diseases. Clin. Exp. Allergy 2001, 31, 1509-1514. [CrossRef] [PubMed]

58. Hussein, Y.M.; Shalaby, S.M.; Nassar, A.; Alzahrani, S.S.; Alharbi, A.S.; Nouh, M. Association between genes encoding components of the IL-4/IL-4 receptor pathway and dermatitis in children. Gene 2014, 545, $276-281$. [CrossRef] [PubMed]

59. Casaca, V.I.; Illi, S.; Klucker, E.; Ballenberger, N.; Schedel, M.; von Mutius, E.; Kabesch, M.; Schaub, B. STAT6 polymorphisms are associated with neonatal regulatory $\mathrm{T}$ cells and cytokines and atopic diseases at 3 years. Allergy 2013, 68, 1249-1258. [CrossRef] [PubMed]

60. Sokolowska-Wojdylo, M.; Glen, J.; Zablotna, M.; Rebala, K.; Trzeciak, M.; Sikorska, M.; Ruckemann-Dziurdzinska, K.; Nedoszytko, B.; Florek, A.; Nowicki, R. The frequencies of haplotypes defined by three polymorphisms of the IL-31 gene: $-1066,-2057$, and IVS2+12 in Polish patients with atopic dermatitis. Int. J. Dermatol. 2015, 54, 62-67. [CrossRef] [PubMed]

61. Narbutt, J.; Wojtczak, M.; Zalinska, A.; Salinski, A.; Przybylowska-Sygut, K.; Kuna, P.; Majak, P.; Sysa-Jedrzejowska, A.; Lesiak, A. The A/A genotype of an interleukin-17A polymorphism predisposes to increased severity of atopic dermatitis and coexistence with asthma. Clin. Exp. Dermatol. 2015, 40, 11-16. [CrossRef] [PubMed]

62. Hong, C.H.; Yu, H.S.; Ko, Y.C.; Chang, W.C.; Chuang, H.Y.; Chen, G.S.; Lee, C.H. Functional regulation of interleukin-31 production by its genetic polymorphism in patients with extrinsic atopic dermatitis. Acta Derm. Venereol. 2012, 92, 430-432. [CrossRef] [PubMed]

63. Arshad, S.H.; Karmaus, W.; Kurukulaaratchy, R.; Sadeghnejad, A.; Huebner, M.; Ewart, S. Polymorphisms in the interleukin 13 and GATA binding protein 3 genes and the development of eczema during childhood. Br. J. Dermatol. 2008, 158, 1315-1322. [CrossRef] [PubMed]

64. Hussein, P.Y.; Zahran, F.; Ashour Wahba, A.; Ahmad, A.S.; Ibrahiem, M.M.; Shalaby, S.M.; El Tarhouny, S.A.; El Sherbiny, H.M.; Bakr, N. Interleukin 10 receptor $\alpha$ subunit (IL-10RA) gene polymorphism and IL-10 serum levels in Egyptian atopic patients. J. Investig. Allergol. Clin. Immunol. 2010, 20, 20-26. [PubMed]

65. Namkung, J.H.; Lee, J.E.; Kim, E.; Park, G.T.; Yang, H.S.; Jang, H.Y.; Shin, E.S.; Cho, E.Y.; Yang, J.M. An association between IL-9 and IL-9 receptor gene polymorphisms and atopic dermatitis in a Korean population. J. Dermatol. Sci. 2011, 62, 16-21. [CrossRef] [PubMed]

66. Gharagozlou, M.; Farhadi, E.; Khaledi, M.; Behniafard, N.; Sotoudeh, S.; Salari, R.; Darabi, B.; Fathi, S.M.; Mahmoudi, M.; Aghamohammadi, A.; et al. Association between the interleukin 6 genotype at position -174 and atopic dermatitis. J. Investig. Allergol. Clin. Immunol. 2013, 23, 89-93. [PubMed]

67. Namkung, J.H.; Lee, J.E.; Kim, E.; Cho, H.J.; Kim, S.; Shin, E.S.; Cho, E.Y.; Yang, J.M. IL-5 and IL-5 receptor $\alpha$ polymorphisms are associated with atopic dermatitis in Koreans. Allergy 2007, 62, 934-942. [CrossRef] [PubMed]

68. Hoffjan, S.; Beygo, J.; Akkad, D.A.; Parwez, Q.; Petrasch-Parwez, E.; Epplen, J.T. Analysis of variation in the IL7RA and IL2RA genes in atopic dermatitis. J. Dermatol. Sci. 2009, 55, 138-140. [CrossRef] [PubMed]

69. Nickel, R.G.; Casolaro, V.; Wahn, U.; Beyer, K.; Barnes, K.C.; Plunkett, B.S.; Freidhoff, L.R.; Sengler, C.; Plitt, J.R.; Schleimer, R.P.; et al. Atopic dermatitis is associated with a functional mutation in the promoter of the C-C chemokine rantes. J. Immunol. 2000, 164, 1612-1616. [CrossRef] [PubMed]

70. Tanaka, K.; Roberts, M.H.; Yamamoto, N.; Sugiura, H.; Uehara, M.; Hopkin, J.M. Upregulating promoter polymorphisms of rantes relate to atopic dermatitis. Int. J. Immunogenet. 2006, 33, 423-428. [CrossRef] [PubMed] 
71. Yamanaka, K.; Mizutani, H. The role of cytokines/chemokines in the pathogenesis of atopic dermatitis. Curr. Probl. Dermatol. 2011, 41, 80-92. [PubMed]

72. Yu, B.; Shao, Y.; Zhang, J.; Dong, X.L.; Liu, W.L.; Yang, H.; Liu, L.; Li, M.H.; Yue, C.F.; Fang, Z.Y.; et al. Polymorphisms in human histamine receptor $\mathrm{H} 4$ gene are associated with atopic dermatitis. Br. J. Dermatol. 2010, 162, 1038-1043. [CrossRef] [PubMed]

73. Chen, B.; Ye, T.; Shao, Y.; Zhang, J.; Zhong, Q.; Hu, X.; Zhang, W.; Yu, B. Association between copy-number variations of the human histamine $\mathrm{H} 4$ receptor gene and atopic dermatitis in a Chinese population. Clin. Exp. Dermatol. 2013, 38, 295-300. [CrossRef] [PubMed]

74. Niwa, Y.; Potaczek, D.P.; Kanada, S.; Takagi, A.; Shimokawa, N.; Ito, T.; Mitsuishi, K.; Okubo, Y.; Tajima, M.; Hobo, A.; et al. Fcepsilonrialpha gene (FCER1A) promoter polymorphisms and total serum IgE levels in Japanese atopic dermatitis patients. Int. J. Immunogenet. 2010, 37, 139-141. [CrossRef] [PubMed]

75. Park, K.Y.; Park, M.K.; Kim, E.J.; Lee, M.K.; Seo, S.J. Fcepsilonri gene promoter polymorphisms and total IgE levels in susceptibility to atopic dermatitis in korea. J. Korean Med. Sci. 2011, 26, 870-874. [CrossRef] [PubMed]

76. Zhou, J.; Zhou, Y.; Lin, L.H.; Wang, J.; Peng, X.; Li, J.; Li, L. Association of polymorphisms in the promoter region of FCER1A gene with atopic dermatitis, chronic uticaria, asthma, and serum immunoglobulin E levels in a Han Chinese population. Hum. Immunol. 2012, 73, 301-305. [CrossRef] [PubMed]

77. Ma, L.; Gao, X.H.; Zhao, L.P.; Di, Z.H.; McHepange, U.O.; Zhang, L.; Chen, H.D.; Wei, H.C. Brain-derived neurotrophic factor gene polymorphisms and serum levels in chinese atopic dermatitis patients. J. Eur. Acad. Dermatol. Venereol. 2009, 23, 1277-1281. [CrossRef] [PubMed]

78. Blakely, K.; Gooderham, M.; Papp, K. Dupilumab, a monoclonal antibody for atopic dermatitis: A review of current literature. Skin Ther. Lett. 2016, 21, 1-5.

79. Wang, D.; Beck, L.A. Immunologic targets in atopic dermatitis and emerging therapies: An update. Am. J. Clin. Dermatol. 2016, 1-19. [CrossRef] [PubMed]

80. Noda, S.; Krueger, J.G.; Guttman-Yassky, E. The translational revolution and use of biologics in patients with inflammatory skin diseases. J. Allergy Clin. Immunol. 2015, 135, 324-336. [CrossRef] [PubMed]

81. Liang, Y.; Chang, C.; Lu, Q. The genetics and epigenetics of atopic dermatitis-filaggrin and other polymorphisms. Clin. Rev. Allergy Immunol. 2015. [CrossRef] [PubMed]

82. Herberth, G.; Bauer, M.; Gasch, M.; Hinz, D.; Roder, S.; Olek, S.; Kohajda, T.; Rolle-Kampczyk, U.; von Bergen, M.; Sack, U.; et al. Maternal and cord blood mir-223 expression associates with prenatal tobacco smoke exposure and low regulatory T-cell numbers. J. Allergy Clin. Immunol. 2014, 133, 543-550. [CrossRef] [PubMed]

83. Hinz, D.; Bauer, M.; Roder, S.; Olek, S.; Huehn, J.; Sack, U.; Borte, M.; Simon, J.C.; Lehmann, I.; Herberth, G. Cord blood tregs with stable FOXP3 expression are influenced by prenatal environment and associated with atopic dermatitis at the age of one year. Allergy 2012, 67, 380-389. [CrossRef] [PubMed]

84. Ahn, K. The role of air pollutants in atopic dermatitis. J. Allergy Clin. Immunol. 2014, 134, 993-999. [CrossRef] [PubMed]

85. Wang, I.J.; Guo, Y.L.; Lin, T.J.; Chen, P.C.; Wu, Y.N. GSTM1, GSTP1, prenatal smoke exposure, and atopic dermatitis. Ann. Allergy Asthma Immunol. 2010, 105, 124-129. [CrossRef] [PubMed]

86. Wang, I.J.; Chen, S.L.; Lu, T.P.; Chuang, E.Y.; Chen, P.C. Prenatal smoke exposure, DNA methylation, and childhood atopic dermatitis. Clin. Exp. Allergy 2013, 43, 535-543. [CrossRef] [PubMed]

87. Nakamura, T.; Sekigawa, I.; Ogasawara, H.; Mitsuishi, K.; Hira, K.; Ikeda, S.; Ogawa, H. Expression of DNMT-1 in patients with atopic dermatitis. Arch. Dermatol. Res. 2006, 298, 253-256. [CrossRef] [PubMed]

88. Liang, Y.; Wang, P.; Zhao, M.; Liang, G.; Yin, H.; Zhang, G.; Wen, H.; Lu, Q. Demethylation of the FCER1G promoter leads to fcepsilonri overexpression on monocytes of patients with atopic dermatitis. Allergy 2012, 67, 424-430. [CrossRef] [PubMed]

89. Sonkoly, E.; Janson, P.; Majuri, M.L.; Savinko, T.; Fyhrquist, N.; Eidsmo, L.; Xu, N.; Meisgen, F.; Wei, T.; Bradley, M.; et al. miR-155 is overexpressed in patients with atopic dermatitis and modulates T-cell proliferative responses by targeting cytotoxic T lymphocyte-associated antigen 4. J. Allergy Clin. Immunol. 2010, 126, 581-589. [CrossRef] [PubMed]

90. Ma, L.; Xue, H.B.; Wang, F.; Shu, C.M.; Zhang, J.H. MicroRNA-155 may be involved in the pathogenesis of atopic dermatitis by modulating the differentiation and function of T Helper type 17 (Th17) cells. Clin. Exp. Immunol. 2015, 181, 142-149. [CrossRef] [PubMed] 
91. Rebane, A.; Runnel, T.; Aab, A.; Maslovskaja, J.; Ruckert, B.; Zimmermann, M.; Plaas, M.; Karner, J.; Treis, A.; Pihlap, M.; et al. MicroRNA-146A alleviates chronic skin inflammation in atopic dermatitis through suppression of innate immune responses in keratinocytes. J. Allergy Clin. Immunol. 2014, 134, 836-847. [CrossRef] [PubMed]

92. Zeng, Y.P.; Nguyen, G.H.; Jin, H.Z. MicroRNA-143 inhibits IL-13-induced dysregulation of the epidermal barrier-related proteins in skin keratinocytes via targeting to IL-13r $\alpha 1$. Mol. Cell. Biochem. 2016, 416, 63-70. [CrossRef] [PubMed]

93. Dinarello, C.A. Immunological and inflammatory functions of the interleukin-1 family. Annu. Rev. Immunol. 2009, 27, 519-550. [CrossRef] [PubMed]

94. Hachem, J.P.; Wagberg, F.; Schmuth, M.; Crumrine, D.; Lissens, W.; Jayakumar, A.; Houben, E.; Mauro, T.M.; Leonardsson, G.; Brattsand, M.; et al. Serine protease activity and residual lekti expression determine phenotype in netherton syndrome. J. Investig. Dermatol. 2006, 126, 1609-1621. [CrossRef] [PubMed]

95. Briot, A.; Deraison, C.; Lacroix, M.; Bonnart, C.; Robin, A.; Besson, C.; Dubus, P.; Hovnanian, A. Kallikrein 5 induces atopic dermatitis-like lesions through PAR2-mediated thymic stromal lymphopoietin expression in netherton syndrome. J. Exp. Med. 2009, 206, 1135-1147. [CrossRef] [PubMed]

96. Kim, J.H.; Bae, H.C.; Ko, N.Y.; Lee, S.H.; Jeong, S.H.; Lee, H.; Ryu, W.I.; Kye, Y.C.; Son, S.W. Thymic stromal lymphopoietin downregulates filaggrin expression by signal transducer and activator of transcription 3 (STAT3) and extracellular signal-regulated kinase (ERK) phosphorylation in keratinocytes. J. Allergy Clin. Immunol. 2015, 136, 205-208. [CrossRef] [PubMed]

97. Andoh, T.; Kuraishi, Y. Antipruritic mechanisms of topical e6005, a phosphodiesterase 4 inhibitor: Inhibition of responses to proteinase-activated receptor 2 stimulation mediated by increase in intracellular cyclic amp. J. Dermatol. Sci. 2014, 76, 206-213. [CrossRef] [PubMed]

98. Volf, E.M.; Au, S.C.; Dumont, N.; Scheinman, P.; Gottlieb, A.B. A phase 2, open-label, investigator-initiated study to evaluate the safety and efficacy of apremilast in subjects with recalcitrant allergic contact or atopic dermatitis. J. Drugs Dermatol. 2012, 11, 341-346. [PubMed]

99. Samrao, A.; Berry, T.M.; Goreshi, R.; Simpson, E.L. A pilot study of an oral phosphodiesterase inhibitor (apremilast) for atopic dermatitis in adults. Arch. Dermatol. 2012, 148, 890-897. [CrossRef] [PubMed]

100. Pellerin, L.; Henry, J.; Hsu, C.Y.; Balica, S.; Jean-Decoster, C.; Mechin, M.C.; Hansmann, B.; Rodriguez, E.; Weindinger, S.; Schmitt, A.M.; et al. Defects of filaggrin-like proteins in both lesional and nonlesional atopic skin. J. Allergy Clin. Immunol. 2013, 131, 1094-1102. [CrossRef] [PubMed]

101. Jensen, J.M.; Pfeiffer, S.; Witt, M.; Brautigam, M.; Neumann, C.; Weichenthal, M.; Schwarz, T.; Folster-Holst, R.; Proksch, E. Different effects of pimecrolimus and betamethasone on the skin barrier in patients with atopic dermatitis. J. Allergy Clin. Immunol. 2009, 123, 1124-1133. [CrossRef] [PubMed]

102. Otsuka, A.; Doi, H.; Egawa, G.; Maekawa, A.; Fujita, T.; Nakamizo, S.; Nakashima, C.; Nakajima, S.; Watanabe, T.; Miyachi, Y.; et al. Possible new therapeutic strategy to regulate atopic dermatitis through upregulating filaggrin expression. J. Allergy Clin. Immunol. 2014, 133, 139-146. [CrossRef] [PubMed]

103. Stout, T.E.; McFarland, T.; Mitchell, J.C.; Appukuttan, B.; Stout, J.T. Recombinant filaggrin is internalized and processed to correct filaggrin deficiency. J. Investig. Dermatol. 2014, 134, 423-429. [CrossRef] [PubMed]

104. De Benedetto, A.; Slifka, M.K.; Rafaels, N.M.; Kuo, I.H.; Georas, S.N.; Boguniewicz, M.; Hata, T.; Schneider, L.C.; Hanifin, J.M.; Gallo, R.L.; et al. Reductions in claudin-1 may enhance susceptibility to herpes simplex virus 1 infections in atopic dermatitis. J. Allergy Clin. Immunol. 2011, 128, 242-246. [CrossRef] [PubMed]

105. Gruber, R.; Bornchen, C.; Rose, K.; Daubmann, A.; Volksdorf, T.; Wladykowski, E.; Vidal, Y.S.S.; Peters, E.M.; Danso, M.; Bouwstra, J.A.; et al. Diverse regulation of claudin-1 and claudin-4 in atopic dermatitis. Am. J. Pathol. 2015, 185, 2777-2789. [CrossRef] [PubMed]

106. Kuo, I.H.; Carpenter-Mendini, A.; Yoshida, T.; McGirt, L.Y.; Ivanov, A.I.; Barnes, K.C.; Gallo, R.L.; Borkowski, A.W.; Yamasaki, K.; Leung, D.Y.; et al. Activation of epidermal Toll-Like receptor 2 enhances tight junction function: Implications for atopic dermatitis and skin barrier repair. J. Investig. Dermatol. 2013, 133, 988-998. [CrossRef] [PubMed]

107. Suarez-Farinas, M.; Tintle, S.J.; Shemer, A.; Chiricozzi, A.; Nograles, K.; Cardinale, I.; Duan, S.; Bowcock, A.M.; Krueger, J.G.; Guttman-Yassky, E. Nonlesional atopic dermatitis skin is characterized by broad terminal differentiation defects and variable immune abnormalities. J. Allergy Clin. Immunol. 2011, 127, 954-964. [CrossRef] [PubMed] 
108. Janssens, M.; van Smeden, J.; Gooris, G.S.; Bras, W.; Portale, G.; Caspers, P.J.; Vreeken, R.J.; Hankemeier, T.; Kezic, S.; Wolterbeek, R.; et al. Increase in short-chain ceramides correlates with an altered lipid organization and decreased barrier function in atopic eczema patients. J. Lipid Res. 2012, 53, 2755-2766. [CrossRef] [PubMed]

109. Van Smeden, J.; Janssens, M.; Kaye, E.C.; Caspers, P.J.; Lavrijsen, A.P.; Vreeken, R.J.; Bouwstra, J.A. The importance of free fatty acid chain length for the skin barrier function in atopic eczema patients. Exp. Dermatol. 2014, 23, 45-52. [CrossRef] [PubMed]

110. Sawada, E.; Yoshida, N.; Sugiura, A.; Imokawa, G. Th1 cytokines accentuate but Th2 cytokines attenuate ceramide production in the stratum corneum of human epidermal equivalents: An implication for the disrupted barrier mechanism in atopic dermatitis. J. Dermatol. Sci. 2012, 68, 25-35. [CrossRef] [PubMed]

111. Ong, P.Y.; Ohtake, T.; Brandt, C.; Strickland, I.; Boguniewicz, M.; Ganz, T.; Gallo, R.L.; Leung, D.Y. Endogenous antimicrobial peptides and skin infections in atopic dermatitis. N. Engl. J. Med. 2002, 347, 1151-1160. [CrossRef] [PubMed]

112. Howell, M.D.; Novak, N.; Bieber, T.; Pastore, S.; Girolomoni, G.; Boguniewicz, M.; Streib, J.; Wong, C.; Gallo, R.L.; Leung, D.Y. Interleukin-10 downregulates anti-microbial peptide expression in atopic dermatitis. J. Investig. Dermatol. 2005, 125, 738-745. [CrossRef] [PubMed]

113. Schittek, B. The antimicrobial skin barrier in patients with atopic dermatitis. Curr. Probl. Dermatol. 2011, 41, 54-67. [PubMed]

114. Son, E.D.; Kim, H.J.; Kim, K.H.; Bin, B.H.; Bae, I.H.; Lim, K.M.; Yu, S.J.; Cho, E.G.; Lee, T.R. S100a7 (psoriasin) inhibits human epidermal differentiation by enhanced IL-6 secretion through IкB/NF- $\mathrm{kB}$ signaling. Exp. Dermatol. 2016, 25, 636-641. [CrossRef] [PubMed]

115. Niebuhr, M.; Langnickel, J.; Sigel, S.; Werfel, T. Dysregulation of CD36 upon TLR-2 stimulation in monocytes from patients with atopic dermatitis and the TLR2 R753Q polymorphism. Exp. Dermatol. 2010, 19, e296-e298. [CrossRef] [PubMed]

116. Camargo, C.A., Jr.; Ganmaa, D.; Sidbury, R.; Erdenedelger, K.; Radnaakhand, N.; Khandsuren, B. Randomized trial of vitamin d supplementation for winter-related atopic dermatitis in children. J. Allergy Clin. Immunol. 2014, 134, 831-835. [CrossRef] [PubMed]

117. Hata, T.R.; Audish, D.; Kotol, P.; Coda, A.; Kabigting, F.; Miller, J.; Alexandrescu, D.; Boguniewicz, M.; Taylor, P.; Aertker, L.; et al. A randomized controlled double-blind investigation of the effects of vitamin D dietary supplementation in subjects with atopic dermatitis. J. Eur. Acad. Dermatol. Venereol. 2014, 28, 781-789. [CrossRef] [PubMed]

118. Nygaard, U.; Hvid, M.; Johansen, C.; Buchner, M.; Folster-Holst, R.; Deleuran, M.; Vestergaard, C. TSLP, IL-31, IL-33 and SST2 are new biomarkers in endophenotypic profiling of adult and childhood atopic dermatitis. J. Eur. Acad. Dermatol. Venereol. 2016. [CrossRef] [PubMed]

119. Moy, A.P.; Murali, M.; Kroshinsky, D.; Duncan, L.M.; Nazarian, R.M. Immunologic overlap of helper T-cell subtypes 17 and 22 in erythrodermic psoriasis and atopic dermatitis. JAMA Dermatol. 2015, 151, 753-760. [CrossRef] [PubMed]

120. Howell, M.D.; Fairchild, H.R.; Kim, B.E.; Bin, L.; Boguniewicz, M.; Redzic, J.S.; Hansen, K.C.; Leung, D.Y. Th2 cytokines act on S100/A11 to downregulate keratinocyte differentiation. J. Investig. Dermatol. 2008, 128, 2248-2258. [CrossRef] [PubMed]

121. Gittler, J.K.; Shemer, A.; Suarez-Farinas, M.; Fuentes-Duculan, J.; Gulewicz, K.J.; Wang, C.Q.; Mitsui, H.; Cardinale, I.; de Guzman Strong, C.; Krueger, J.G.; et al. Progressive activation of Th2/Th22 cytokines and selective epidermal proteins characterizes acute and chronic atopic dermatitis. J. Allergy Clin. Immunol. 2012, 130, 1344-1354. [CrossRef] [PubMed]

122. Sehra, S.; Yao, Y.; Howell, M.D.; Nguyen, E.T.; Kansas, G.S.; Leung, D.Y.; Travers, J.B.; Kaplan, M.H. IL-4 regulates skin homeostasis and the predisposition toward allergic skin inflammation. J. Immunol. 2010, 184, 3186-3190. [CrossRef] [PubMed]

123. Kim, B.E.; Leung, D.Y.; Boguniewicz, M.; Howell, M.D. Loricrin and involucrin expression is down-regulated by Th2 cytokines through STAT-6. Clin. Immunol. 2008, 126, 332-337. [CrossRef] [PubMed]

124. Howell, M.D.; Kim, B.E.; Gao, P.; Grant, A.V.; Boguniewicz, M.; Debenedetto, A.; Schneider, L.; Beck, L.A.; Barnes, K.C.; Leung, D.Y. Cytokine modulation of atopic dermatitis filaggrin skin expression. J. Allergy Clin. Immunol. 2007, 120, 150-155. [CrossRef] [PubMed] 
125. McAleer, M.A.; Irvine, A.D. The multifunctional role of filaggrin in allergic skin disease. J. Allergy Clin. Immunol. 2013, 131, 280-291. [CrossRef] [PubMed]

126. Amano, W.; Nakajima, S.; Kunugi, H.; Numata, Y.; Kitoh, A.; Egawa, G.; Dainichi, T.; Honda, T.; Otsuka, A.; Kimoto, Y.; et al. The janus kinase inhibitor JTE-052 improves skin barrier function through suppressing signal transducer and activator of transcription 3 signaling. J. Allergy Clin. Immunol. 2015, 136, 667-677. [CrossRef] [PubMed]

127. Thaci, D.; Simpson, E.L.; Beck, L.A.; Bieber, T.; Blauvelt, A.; Papp, K.; Soong, W.; Worm, M.; Szepietowski, J.C.; Sofen, H.; et al. Efficacy and safety of dupilumab in adults with moderate-to-severe atopic dermatitis inadequately controlled by topical treatments: A randomised, placebo-controlled, dose-ranging phase 2B trial. Lancet 2016, 387, 40-52. [CrossRef]

128. Toda, M.; Leung, D.Y.; Molet, S.; Boguniewicz, M.; Taha, R.; Christodoulopoulos, P.; Fukuda, T.; Elias, J.A.; Hamid, Q.A. Polarized in vivo expression of IL-11 and IL-17 between acute and chronic skin lesions. J. Allergy Clin. Immunol. 2003, 111, 875-881. [CrossRef] [PubMed]

129. Nograles, K.E.; Zaba, L.C.; Shemer, A.; Fuentes-Duculan, J.; Cardinale, I.; Kikuchi, T.; Ramon, M.; Bergman, R.; Krueger, J.G.; Guttman-Yassky, E. IL-22-producing “T22” T cells account for upregulated IL-22 in atopic dermatitis despite reduced IL-17-producing Th17 T cells. J. Allergy Clin. Immunol. 2009, 123, 1244-1252. [CrossRef] [PubMed]

130. Park, H.; Li, Z.; Yang, X.O.; Chang, S.H.; Nurieva, R.; Wang, Y.H.; Wang, Y.; Hood, L.; Zhu, Z.; Tian, Q.; et al. A distinct lineage of CD4 T cells regulates tissue inflammation by producing interleukin 17. Nat. Immunol. 2005, 6, 1133-1141. [CrossRef] [PubMed]

131. Jin, S.; Park, C.O.; Shin, J.U.; Noh, J.Y.; Lee, Y.S.; Lee, N.R.; Kim, H.R.; Noh, S.; Lee, Y.; Lee, J.H.; et al. Damp molecules S100A9 and S100A8 activated by IL-17A and house-dust mites are increased in atopic dermatitis. Exp. Dermatol. 2014, 23, 938-941. [CrossRef] [PubMed]

132. Suarez-Farinas, M.; Dhingra, N.; Gittler, J.; Shemer, A.; Cardinale, I.; de Guzman Strong, C.; Krueger, J.G.; Guttman-Yassky, E. Intrinsic atopic dermatitis shows similar Th2 and higher Th17 immune activation compared with extrinsic atopic dermatitis. J. Allergy Clin. Immunol. 2013, 132, 361-370. [CrossRef] [PubMed]

133. Noda, S.; Suarez-Farinas, M.; Ungar, B.; Kim, S.J.; de Guzman Strong, C.; Xu, H.; Peng, X.; Estrada, Y.D.; Nakajima, S.; Honda, T.; et al. The asian atopic dermatitis phenotype combines features of atopic dermatitis and psoriasis with increased Th17 polarization. J. Allergy Clin. Immunol. 2015, 136, 1254-1264. [CrossRef] [PubMed]

134. Czarnowicki, T.; Gonzalez, J.; Shemer, A.; Malajian, D.; Xu, H.; Zheng, X.; Khattri, S.; Gilleaudeau, P.; Sullivan-Whalen, M.; Suarez-Farinas, M.; et al. Severe atopic dermatitis is characterized by selective expansion of circulating TH2/TC2 and TH22/TC22, but not TH17/TC17, cells within the skin-homing T-cell population. J. Allergy Clin. Immunol. 2015, 136, 104-115. [CrossRef] [PubMed]

135. Gutowska-Owsiak, D.; Schaupp, A.L.; Salimi, M.; Taylor, S.; Ogg, G.S. Interleukin-22 downregulates filaggrin expression and affects expression of profilaggrin processing enzymes. Br. J. Dermatol. 2011, 165, 492-498. [CrossRef] [PubMed]

136. Wolk, K.; Witte, E.; Wallace, E.; Docke, W.D.; Kunz, S.; Asadullah, K.; Volk, H.D.; Sterry, W.; Sabat, R. IL-22 regulates the expression of genes responsible for antimicrobial defense, cellular differentiation, and mobility in keratinocytes: A potential role in psoriasis. Eur. J. Immunol. 2006, 36, 1309-1323. [CrossRef] [PubMed]

137. Niebuhr, M.; Mainardy, J.; Heratizadeh, A.; Satzger, I.; Werfel, T. Staphylococcal exotoxins induce interleukin 22 in human Th22 cells. Int. Arch. Allergy Immunol. 2014, 165, 35-39. [CrossRef] [PubMed]

138. Jang, M.; Kim, H.; Kim, Y.; Choi, J.; Jeon, J.; Hwang, Y.; Kang, J.S.; Lee, W.J. The crucial role of IL-22 and its receptor on tarc production and T cell migration by HDM extract. Exp. Dermatol. 2016, 25, 598-603. [CrossRef] [PubMed]

139. Boniface, K.; Bernard, F.X.; Garcia, M.; Gurney, A.L.; Lecron, J.C.; Morel, F. IL-22 inhibits epidermal differentiation and induces proinflammatory gene expression and migration of human keratinocytes. J. Immunol. 2005, 174, 3695-3702. [CrossRef] [PubMed]

140. Wu, P.W.; Li, J.; Kodangattil, S.R.; Luxenberg, D.P.; Bennett, F.; Martino, M.; Collins, M.; Dunussi-Joannopoulos, K.; Gill, D.S.; Wolfman, N.M.; et al. IL-22R, IL-10R2, and IL-22BP binding sites are topologically juxtaposed on adjacent and overlapping surfaces of IL-22. J. Mol. Biol. 2008, 382, 1168-1183. [CrossRef] [PubMed] 
141. Witte, E.; Witte, K.; Warszawska, K.; Sabat, R.; Wolk, K. Interleukin-22: A cytokine produced by T, NK and NKT cell subsets, with importance in the innate immune defense and tissue protection. Cytokine Growth Factor Rev. 2010, 21, 365-379. [CrossRef] [PubMed]

142. Alam, M.S.; Maekawa, Y.; Kitamura, A.; Tanigaki, K.; Yoshimoto, T.; Kishihara, K.; Yasutomo, K. Notch signaling drives IL-22 secretion in $\mathrm{CD}^{+} \mathrm{T}$ cells by stimulating the aryl hydrocarbon receptor. Proc. Natl. Acad. Sci. USA 2010, 107, 5943-5948. [CrossRef] [PubMed]

143. Czarnowicki, T.; Esaki, H.; Gonzalez, J.; Malajian, D.; Shemer, A.; Noda, S.; Talasila, S.; Berry, A.; Gray, J.; Becker, L.; et al. Early pediatric atopic dermatitis shows only a cutaneous lymphocyte antigen (CLA)(+) $\mathrm{TH} 2 / \mathrm{TH} 1$ cell imbalance, whereas adults acquire CLA+ TH22/TC22 cell subsets. J. Allergy Clin. Immunol. 2015, 136, 941-951. [CrossRef] [PubMed]

144. Inoue, Y.; Aihara, M.; Kirino, M.; Harada, I.; Komori-Yamaguchi, J.; Yamaguchi, Y.; Nagashima, Y.; Ikezawa, Z. Interleukin-18 is elevated in the horny layer in patients with atopic dermatitis and is associated with staphylococcus aureus colonization. Br. J. Dermatol. 2011, 164, 560-567. [CrossRef] [PubMed]

145. Kim, B.S.; Choi, J.K.; Jung, H.J.; Park, K.H.; Jang, Y.H.; Lee, W.J.; Lee, S.J.; Kim, S.H.; Kang, H.Y.; Kim, J.M.; et al. Effects of topical application of a recombinant staphylococcal enterotoxin a on dncb and dust mite extract-induced atopic dermatitis-like lesions in a murine model. Eur. J. Dermatol. 2014, 24, 186-193. [PubMed]

146. Lee, J.H.; Cho, D.H.; Park, H.J. IL-18 and cutaneous inflammatory diseases. Int. J. Mol. Sci. 2015, 16, 29357-29369. [CrossRef] [PubMed]

147. Novak, N.; Valenta, R.; Bohle, B.; Laffer, S.; Haberstok, J.; Kraft, S.; Bieber, T. Fcepsilonri engagement of langerhans cell-like dendritic cells and inflammatory dendritic epidermal cell-like dendritic cells induces chemotactic signals and different T-cell phenotypes in vitro. J. Allergy Clin. Immunol. 2004, 113, 949-957. [CrossRef] [PubMed]

148. Yoshimoto, T.; Tsutsui, H.; Tominaga, K.; Hoshino, K.; Okamura, H.; Akira, S.; Paul, W.E.; Nakanishi, K. IL-18, although antiallergic when administered with IL-12, stimulates IL-4 and histamine release by basophils. Proc. Natl. Acad. Sci. USA 1999, 96, 13962-13966. [CrossRef] [PubMed]

149. Hoshino, T.; Yagita, H.; Ortaldo, J.R.; Wiltrout, R.H.; Young, H.A. In vivo administration of IL-18 can induce IgE production through Th2 cytokine induction and up-regulation of CD40 ligand (CD154) expression on $\mathrm{CD}^{+}$T cells. Eur. J. Immunol. 2000, 30, 1998-2006. [CrossRef]

150. Lee, H.J.; Kwon, Y.S.; Park, C.O.; Oh, S.H.; Lee, J.H.; Wu, W.H.; Chang, N.S.; Lee, M.G.; Lee, K.H. Corticotropin-releasing factor decreases IL-18 in the monocyte-derived dendritic cell. Exp. Dermatol. 2009, 18, 199-204. [CrossRef] [PubMed]

151. Konishi, H.; Tsutsui, H.; Murakami, T.; Yumikura-Futatsugi, S.; Yamanaka, K.; Tanaka, M.; Iwakura, Y.; Suzuki, N.; Takeda, K.; Akira, S.; et al. IL-18 contributes to the spontaneous development of atopic dermatitis-like inflammatory skin lesion independently of IgE/STAT6 under specific pathogen-free conditions. Proc. Natl. Acad. Sci. USA 2002, 99, 11340-11345. [CrossRef] [PubMed]

152. Jin, J.J.; Zou, Y.X.; Zeng, S.W. Risk factors for and expression of immune and inflammatory factors in atopic dermatitis in chinese population: A birth cohort study. Mol. Cell. Probes 2016, 30, 168-173. [CrossRef] [PubMed]

153. Tanaka, T.; Tsutsui, H.; Yoshimoto, T.; Kotani, M.; Matsumoto, M.; Fujita, A.; Wang, W.; Higa, S.; Koshimoto, T.; Nakanishi, K.; et al. Interleukin-18 is elevated in the sera from patients with atopic dermatitis and from atopic dermatitis model mice, NC/NGA. Int. Arch. Allergy Immunol. 2001, 125, 236-240. [CrossRef] [PubMed]

154. Thijs, J.; Krastev, T.; Weidinger, S.; Buckens, C.F.; de Bruin-Weller, M.; Bruijnzeel-Koomen, C.; Flohr, C.; Hijnen, D. Biomarkers for atopic dermatitis: A systematic review and meta-analysis. Curr. Opin. Allergy Clin. Immunol. 2015, 15, 453-460. [CrossRef] [PubMed]

155. Zedan, K.; Rasheed, Z.; Farouk, Y.; Alzolibani, A.A.; Bin Saif, G.; Ismail, H.A.; Al Robaee, A.A. Immunoglobulin E, interleukin-18 and interleukin-12 in patients with atopic dermatitis: Correlation with disease activity. J. Clin. Diagn. Res. 2015, 9, Wc01-Wc05. [CrossRef] [PubMed]

156. Sonkoly, E.; Muller, A.; Lauerma, A.I.; Pivarcsi, A.; Soto, H.; Kemeny, L.; Alenius, H.; Dieu-Nosjean, M.C.; Meller, S.; Rieker, J.; et al. IL-31: A new link between $\mathrm{t}$ cells and pruritus in atopic skin inflammation. J. Allergy Clin. Immunol. 2006, 117, 411-417. [CrossRef] [PubMed] 
157. Ezzat, M.H.; Hasan, Z.E.; Shaheen, K.Y. Serum measurement of interleukin-31 (IL-31) in paediatric atopic dermatitis: Elevated levels correlate with severity scoring. J. Eur. Acad. Dermatol. Venereol. 2011, 25, 334-339. [CrossRef] [PubMed]

158. Cornelissen, C.; Marquardt, Y.; Czaja, K.; Wenzel, J.; Frank, J.; Luscher-Firzlaff, J.; Luscher, B.; Baron, J.M. IL-31 regulates differentiation and filaggrin expression in human organotypic skin models. J. Allergy Clin. Immunol. 2012, 129, 426-433. [CrossRef] [PubMed]

159. Danso, M.O.; van Drongelen, V.; Mulder, A.; van Esch, J.; Scott, H.; van Smeden, J.; El Ghalbzouri, A.; Bouwstra, J.A. TNF- $\alpha$ and Th2 cytokines induce atopic dermatitis-like features on epidermal differentiation proteins and stratum corneum lipids in human skin equivalents. J. Investig. Dermatol. 2014, 134, 1941-1950. [PubMed]

160. Zhang, Q.; Putheti, P.; Zhou, Q.; Liu, Q.; Gao, W. Structures and biological functions of IL-31 and IL-31 receptors. Cytokine Growth Factor Rev. 2008, 19, 347-356. [CrossRef] [PubMed]

161. Kato, A.; Fujii, E.; Watanabe, T.; Takashima, Y.; Matsushita, H.; Furuhashi, T.; Morita, A. Distribution of IL-31 and its receptor expressing cells in skin of atopic dermatitis. J. Dermatol. Sci. 2014, 74, 229-235. [CrossRef] [PubMed]

162. Feld, M.; Garcia, R.; Buddenkotte, J.; Katayama, S.; Lewis, K.; Muirhead, G.; Hevezi, P.; Plesser, K.; Schrumpf, H.; Krjutskov, K.; et al. The pruritus- and TH2-associated cytokine IL-31 promotes growth of sensory nerves. J. Allergy Clin. Immunol. 2016. [CrossRef] [PubMed]

163. Nemoto, O.; Furue, M.; Nakagawa, H.; Shiramoto, M.; Hanada, R.; Matsuki, S.; Imayama, S.; Kato, M.; Hasebe, I.; Taira, K.; et al. The first trial of CIM331, a humanized antihuman interleukin-31 receptor a antibody, in healthy volunteers and patients with atopic dermatitis to evaluate safety, tolerability and pharmacokinetics of a single dose in a randomized, double-blind, placebo-controlled study. Br. J. Dermatol. 2016, 174, 296-304. [PubMed]

164. Lee, C.H.; Hong, C.H.; Yu, W.T.; Chuang, H.Y.; Huang, S.K.; Chen, G.S.; Yoshioka, T.; Sakata, M.; Liao, W.T.; Ko, Y.C.; et al. Mechanistic correlations between two itch biomarkers, cytokine interleukin-31 and neuropeptide beta-endorphin, via STAT3/calcium axis in atopic dermatitis. Br. J. Dermatol. 2012, 167, 794-803. [CrossRef] [PubMed]

165. Hawro, T.; Saluja, R.; Weller, K.; Altrichter, S.; Metz, M.; Maurer, M. Interleukin-31 does not induce immediate itch in atopic dermatitis patients and healthy controls after skin challenge. Allergy 2014, 69, 113-117. [CrossRef] [PubMed]

166. Hanel, K.H.; Pfaff, C.M.; Cornelissen, C. Control of the physical and antimicrobial skin barrier by an IL-31-IL-1 signaling network. J. Immunol. 2016, 196, 3233-3244. [CrossRef] [PubMed]

167. Jirapongsananuruk, O.; Hofer, M.F.; Trumble, A.E.; Norris, D.A.; Leung, D.Y. Enhanced expression of B7.2 (CD86) in patients with atopic dermatitis: A potential role in the modulation of IgE synthesis. J. Immunol. 1998, 160, 4622-4627. [PubMed]

168. Navarrete-Dechent, C.; Perez-Mateluna, G.; Silva-Valenzuela, S.; Vera-Kellet, C.; Borzutzky, A. Humoral and cellular autoreactivity to epidermal proteins in atopic dermatitis. Arch. Immunol. Ther. Exp. 2016. [CrossRef] [PubMed]

169. Heil, P.M.; Maurer, D.; Klein, B.; Hultsch, T.; Stingl, G. Omalizumab therapy in atopic dermatitis: Depletion of IgE does not improve the clinical course-A randomized, placebo-controlled and double blind pilot study. J. Dtsch. Dermatol. Ges. 2010, 8, 990-998. [CrossRef] [PubMed]

170. Simon, D.; Hosli, S.; Kostylina, G.; Yawalkar, N.; Simon, H.U. Anti-CD20 (rituximab) treatment improves atopic eczema. J. Allergy Clin. Immunol. 2008, 121, 122-128. [CrossRef] [PubMed]

171. Wollenberg, A.; Wen, S.; Bieber, T. Phenotyping of epidermal dendritic cells: Clinical applications of a flow cytometric micromethod. Cytometry 1999, 37, 147-155. [CrossRef]

172. Wollenberg, A.; Sharma, S.; von Bubnoff, D.; Geiger, E.; Haberstok, J.; Bieber, T. Topical tacrolimus (FK506) leads to profound phenotypic and functional alterations of epidermal antigen-presenting dendritic cells in atopic dermatitis. J. Allergy Clin. Immunol. 2001, 107, 519-525. [CrossRef] [PubMed]

173. Wollenberg, A.; Wagner, M.; Gunther, S.; Towarowski, A.; Tuma, E.; Moderer, M.; Rothenfusser, S.; Wetzel, S.; Endres, S.; Hartmann, G. Plasmacytoid dendritic cells: A new cutaneous dendritic cell subset with distinct role in inflammatory skin diseases. J. Investig. Dermatol. 2002, 119, 1096-1102. [CrossRef] [PubMed] 
174. Ito, T.; Wang, Y.H.; Duramad, O.; Hori, T.; Delespesse, G.J.; Watanabe, N.; Qin, F.X.; Yao, Z.; Cao, W.; Liu, Y.J. TSLP-activated dendritic cells induce an inflammatory T helper type 2 cell response through OX40 ligand. J. Exp. Med. 2005, 202, 1213-1223. [CrossRef] [PubMed]

175. Gros, E.; Petzold, S.; Maintz, L.; Bieber, T.; Novak, N. Reduced ifn-gamma receptor expression and attenuated IFN- $\gamma$ response by dendritic cells in patients with atopic dermatitis. J. Allergy Clin. Immunol. 2011, 128, 1015-1021. [CrossRef] [PubMed]

176. Ziegler, S.F. Thymic stromal lymphopoietin and allergic disease. J. Allergy Clin. Immunol. 2012, 130, 845-852. [CrossRef] [PubMed]

177. Fujita, H.; Nograles, K.E.; Kikuchi, T.; Gonzalez, J.; Carucci, J.A.; Krueger, J.G. Human langerhans cells induce distinct IL-22-producing CD4 ${ }^{+}$T cells lacking IL-17 production. Proc. Natl. Acad. Sci. USA 2009, 106, 21795-21800. [CrossRef] [PubMed]

178. Dijkstra, D.; Stark, H.; Chazot, P.L.; Shenton, F.C.; Leurs, R.; Werfel, T.; Gutzmer, R. Human inflammatory dendritic epidermal cells express a functional histamine H4 receptor. J. Investig. Dermatol. 2008, 128, 1696-1703. [CrossRef] [PubMed]

179. Gschwandtner, M.; Schakel, K.; Werfel, T.; Gutzmer, R. Histamine H4 receptor activation on human slan-dendritic cells down-regulates their pro-inflammatory capacity. Immunology 2011, 132, 49-56. [CrossRef] [PubMed]

180. Murray, C.; Ahrens, K.; Devalaraja, M.; Dymond, M.; Fagura, M.; Hargreaves, A.; Holt, A.; Peers, I.; Price, S.; Reens, J.; et al. Use of a canine model of atopic dermatitis to investigate the efficacy of a CCR4 antagonist in allergen-induced skin inflammation in a randomized study. J. Investig. Dermatol. 2016, 136, 665-671. [CrossRef] [PubMed]

181. Morita, E.; Takahashi, H.; Niihara, H.; Dekio, I.; Sumikawa, Y.; Murakami, Y.; Matsunaka, H. Stratum corneum tarc level is a new indicator of lesional skin inflammation in atopic dermatitis. Allergy 2010, 65, 1166-1172. [CrossRef] [PubMed]

182. Miyahara, H.; Okazaki, N.; Nagakura, T.; Korematsu, S.; Izumi, T. Elevated umbilical cord serum TARC/CCL17 levels predict the development of atopic dermatitis in infancy. Clin. Exp. Allergy 2011, 41, 186-191. [CrossRef] [PubMed]

183. Onoue, A.; Kabashima, K.; Kobayashi, M.; Mori, T.; Tokura, Y. Induction of eosinophIL- and Th2-attracting epidermal chemokines and cutaneous late-phase reaction in tape-stripped skin. Exp. Dermatol. 2009, 18, 1036-1043. [CrossRef] [PubMed]

184. Miyano, K.; Matsushita, S.; Tsuchida, T.; Nakamura, K. Inhibitory effect of a histamine 4 receptor antagonist on CCL17 and CCL22 production by monocyte-derived langerhans cells in patients with atopic dermatitis. J. Dermatol. 2016. [CrossRef] [PubMed]

185. Kleinewietfeld, M.; Puentes, F.; Borsellino, G.; Battistini, L.; Rotzschke, O.; Falk, K. CCR6 expression defines regulatory effector/memory-like cells within the CD25+CD4 ${ }^{+}$T-cell subset. Blood 2005, 105, 2877-2886. [CrossRef] [PubMed]

186. Esche, C.; de Benedetto, A.; Beck, L.A. Keratinocytes in atopic dermatitis: Inflammatory signals. Curr. Allergy Asthma Rep. 2004, 4, 276-284. [CrossRef] [PubMed]

187. Gahr, N.; Folster-Holst, R.; Weichenthal, M.; Christophers, E.; Schroder, J.M.; Bartels, J. Dermal fibroblasts from acute inflamed atopic dermatitis lesions display increased eotaxin/CCL11 responsiveness to interleukin-4 stimulation. Br. J. Dermatol. 2011, 164, 586-592. [CrossRef] [PubMed]

188. Yawalkar, N.; Uguccioni, M.; Scharer, J.; Braunwalder, J.; Karlen, S.; Dewald, B.; Braathen, L.R.; Baggiolini, M. Enhanced expression of eotaxin and CCR3 in atopic dermatitis. J. Investig. Dermatol. 1999, 113, 43-48. [CrossRef] [PubMed]

189. Park, C.W.; Lee, B.H.; Han, H.J.; Lee, C.H.; Ahn, H.K. Tacrolimus decreases the expression of eotaxin, CCR3, rantes and interleukin-5 in atopic dermatitis. Br. J. Dermatol. 2005, 152, 1173-1181. [CrossRef] [PubMed]

190. Chong, S.; Lan, H.; Zeng, K.; Zhao, X. Serum fractalkine (CX3CL1) concentration correlates with clinical severity in pediatric atopic dermatitis patients. Ann. Clin. Lab. Sci. 2016, 46, 168-173. [PubMed]

191. Echigo, T.; Hasegawa, M.; Shimada, Y.; Takehara, K.; Sato, S. Expression of fractalkine and its receptor, CX3CR1, in atopic dermatitis: Possible contribution to skin inflammation. J. Allergy Clin. Immunol. 2004, 113, 940-948. [CrossRef] [PubMed] 
192. Siegel, A.M.; Stone, K.D.; Cruse, G.; Lawrence, M.G.; Olivera, A.; Jung, M.Y.; Barber, J.S.; Freeman, A.F.; Holland, S.M.; O'Brien, M.; et al. Diminished allergic disease in patients with STAT3 mutations reveals a role for STAT3 signaling in mast cell degranulation. J. Allergy Clin. Immunol. 2013, 132, 1388-1396. [CrossRef] [PubMed]

193. Mekori, Y.A.; Metcalfe, D.D. Mast cell-T cell interactions. J. Allergy Clin. Immunol. 1999, 104, 517-523. [CrossRef]

194. Theiner, G.; Gessner, A.; Lutz, M.B. The mast cell mediator PGD2 suppresses IL-12 release by dendritic cells leading to Th2 polarized immune responses in vivo. Immunobiology 2006, 211, 463-472. [CrossRef] [PubMed]

195. Horsmanheimo, L.; Harvima, I.T.; Jarvikallio, A.; Harvima, R.J.; Naukkarinen, A.; Horsmanheimo, M. Mast cells are one major source of interleukin-4 in atopic dermatitis. Br. J. Dermatol. 1994, 131, 348-353. [CrossRef] [PubMed]

196. Nagarkar, D.R.; Poposki, J.A.; Comeau, M.R.; Biyasheva, A.; Avila, P.C.; Schleimer, R.P.; Kato, A. Airway epithelial cells activate Th2 cytokine production in mast cells through IL-1 and thymic stromal lymphopoietin. J. Allergy Clin. Immunol. 2012, 130, 225-232. [CrossRef] [PubMed]

197. Gauchat, J.F.; Henchoz, S.; Mazzei, G.; Aubry, J.P.; Brunner, T.; Blasey, H.; Life, P.; Talabot, D.; Flores-Romo, L.; Thompson, J.; et al. Induction of human IgE synthesis in B cells by mast cells and basophils. Nature 1993, 365, 340-343. [CrossRef] [PubMed]

198. Jawdat, D.M.; Albert, E.J.; Rowden, G.; Haidl, I.D.; Marshall, J.S. IgE-mediated mast cell activation induces langerhans cell migration in vivo. J. Immunol. 2004, 173, 5275-5282. [CrossRef] [PubMed]

199. Suto, H.; Nakae, S.; Kakurai, M.; Sedgwick, J.D.; Tsai, M.; Galli, S.J. Mast cell-associated tnf promotes dendritic cell migration. J. Immunol. 2006, 176, 4102-4112. [CrossRef] [PubMed]

200. Modena, B.D.; Dazy, K.; White, A.A. Emerging concepts: Mast cell involvement in allergic diseases. Transl. Res. 2016, 174, 98-121. [CrossRef] [PubMed]

201. Saluja, R.; Ketelaar, M.E.; Hawro, T.; Church, M.K.; Maurer, M.; Nawijn, M.C. The role of the IL-33/IL-1RL1 axis in mast cell and basophil activation in allergic disorders. Mol. Immunol. 2015, 63, 80-85. [CrossRef] [PubMed]

202. Sehra, S.; Serezani, A.P.; Ocana, J.A.; Travers, J.B.; Kaplan, M.H. Mast cells regulate epidermal barrier function and the development of allergic skin inflammation. J. Investig. Dermatol. 2016, 136, 1429-1437. [CrossRef] [PubMed]

203. Simon, D.; Braathen, L.R.; Simon, H.U. Eosinophils and atopic dermatitis. Allergy 2004, 59, 561-570. [CrossRef] [PubMed]

204. Yang, D.; Chen, Q.; Su, S.B.; Zhang, P.; Kurosaka, K.; Caspi, R.R.; Michalek, S.M.; Rosenberg, H.F.; Zhang, N.; Oppenheim, J.J. EosinophIL-derived neurotoxin acts as an alarmin to activate the TLR2-MyD88 signal pathway in dendritic cells and enhances Th2 immune responses. J. Exp. Med. 2008, 205, 79-90. [CrossRef] [PubMed]

205. Abu-Ghazaleh, R.I.; Gleich, G.J.; Prendergast, F.G. Interaction of eosinophil granule major basic protein with synthetic lipid bilayers: A mechanism for toxicity. J. Membr. Biol. 1992, 128, 153-164. [CrossRef] [PubMed]

206. Kagi, M.K.; Joller-Jemelka, H.; Wuthrich, B. Correlation of eosinophils, eosinophil cationic protein and soluble interleukin-2 receptor with the clinical activity of atopic dermatitis. Dermatology 1992, 185, 88-92. [CrossRef] [PubMed]

207. Cheung, P.F.; Wong, C.K.; Ho, A.W.; Hu, S.; Chen, D.P.; Lam, C.W. Activation of human eosinophils and epidermal keratinocytes by Th2 cytokine IL-31: Implication for the immunopathogenesis of atopic dermatitis. Int. Immunol. 2010, 22, 453-467. [CrossRef] [PubMed]

208. Kunsleben, N.; Rudrich, U.; Gehring, M.; Novak, N.; Kapp, A.; Raap, U. IL-31 induces chemotaxis, calcium mobilization, release of reactive oxygen species, and CCL26 in eosinophils, which are capable to release IL-31. J. Investig. Dermatol. 2015, 135, 1908-1911. [CrossRef] [PubMed]

209. Kim, B.S.; Wang, K.; Siracusa, M.C.; Saenz, S.A.; Brestoff, J.R.; Monticelli, L.A.; Noti, M.; Tait Wojno, E.D.; Fung, T.C.; Kubo, M.; et al. Basophils promote innate lymphoid cell responses in inflamed skin. J. Immunol. 2014, 193, 3717-3725. [CrossRef] [PubMed]

210. Jiao, D.; Wong, C.K.; Qiu, H.N.; Dong, J.; Cai, Z.; Chu, M.; Hon, K.L.; Tsang, M.S.; Lam, C.W. NOD2 and TLR2 ligands trigger the activation of basophils and eosinophils by interacting with dermal fibroblasts in atopic dermatitis-like skin inflammation. Cell. Mol. Immunol. 2015. [CrossRef] [PubMed] 
211. Wong, C.K.; Chu, I.M.; Hon, K.L.; Tsang, M.S.; Lam, C.W. Aberrant expression of bacterial pattern recognition receptor NOD2 of basophils and microbicidal peptides in atopic dermatitis. Molecules 2016, $21,417$. [CrossRef] [PubMed]

212. Spits, H.; Cupedo, T. Innate lymphoid cells: Emerging insights in development, lineage relationships, and function. Annu. Rev. Immunol. 2012, 30, 647-675. [CrossRef] [PubMed]

213. Salimi, M.; Barlow, J.L.; Saunders, S.P.; Xue, L.; Gutowska-Owsiak, D.; Wang, X.; Huang, L.C.; Johnson, D.; Scanlon, S.T.; McKenzie, A.N.; et al. A role for IL-25 and IL-33-driven type-2 innate lymphoid cells in atopic dermatitis. J. Exp. Med. 2013, 210, 2939-2950. [CrossRef] [PubMed]

214. Roediger, B.; Kyle, R.; Le Gros, G.; Weninger, W. Dermal group 2 innate lymphoid cells in atopic dermatitis and allergy. Curr. Opin. Immunol. 2014, 31, 108-114. [CrossRef] [PubMed]

215. Doherty, T.A.; Broide, D.H. Group 2 innate lymphoid cells: New players in human allergic diseases. J. Investig. Allergol. Clin. Immunol. 2015, 25, 1-11. [PubMed]

216. Saunders, S.P.; Moran, T.; Floudas, A.; Wurlod, F.; Kaszlikowska, A.; Salimi, M.; Quinn, E.M.; Oliphant, C.J.; Nunez, G.; McManus, R.; et al. Spontaneous atopic dermatitis is mediated by innate immunity, with the secondary lung inflammation of the atopic march requiring adaptive immunity. J. Allergy Clin. Immunol. 2016, 137, 482-491. [CrossRef] [PubMed]

217. Kim, B.S. Innate lymphoid cells in the skin. J. Investig. Dermatol. 2015, 135, 673-678. [CrossRef] [PubMed]

218. Savinko, T.; Matikainen, S.; Saarialho-Kere, U.; Lehto, M.; Wang, G.; Lehtimaki, S.; Karisola, P.; Reunala, T.; Wolff, H.; Lauerma, A.; et al. IL-33 and ST2 in atopic dermatitis: Expression profiles and modulation by triggering factors. J. Investig. Dermatol. 2012, 132, 1392-1400. [CrossRef] [PubMed]

219. Xue, L.; Salimi, M.; Panse, I.; Mjosberg, J.M.; McKenzie, A.N.; Spits, H.; Klenerman, P.; Ogg, G. Prostaglandin D2 activates group 2 innate lymphoid cells through chemoattractant receptor-homologous molecule expressed on Th2 cells. J. Allergy Clin. Immunol. 2014, 133, 1184-1194. [CrossRef] [PubMed]

220. Halim, T.Y.; Hwang, Y.Y.; Scanlon, S.T.; Zaghouani, H.; Garbi, N.; Fallon, P.G.; McKenzie, A.N. Group 2 innate lymphoid cells license dendritic cells to potentiate memory Th2 cell responses. Nat. Immunol. 2016, 17, 57-64. [CrossRef] [PubMed]

221. Roediger, B.; Kyle, R.; Yip, K.H.; Sumaria, N.; Guy, T.V.; Kim, B.S.; Mitchell, A.J.; Tay, S.S.; Jain, R.; Forbes-Blom, E.; et al. Cutaneous immunosurveillance and regulation of inflammation by group 2 innate lymphoid cells. Nat. Immunol. 2013, 14, 564-573. [CrossRef] [PubMed]

222. Kim, B.S.; Siracusa, M.C.; Saenz, S.A.; Noti, M.; Monticelli, L.A.; Sonnenberg, G.F.; Hepworth, M.R.; van Voorhees, A.S.; Comeau, M.R.; Artis, D. Tslp elicits IL-33-independent innate lymphoid cell responses to promote skin inflammation. Sci. Transl. Med. 2013, 5. [CrossRef] [PubMed]

223. Wan, Y.Y. Gata3: A master of many trades in immune regulation. Trends Immunol. 2014, 35, $233-242$. [CrossRef] [PubMed]

224. Ho, I.C.; Tai, T.S.; Pai, S.Y. Gata3 and the T-cell lineage: Essential functions before and after T-helper-2-cell differentiation. Nat. Rev. Immunol. 2009, 9, 125-135. [CrossRef] [PubMed]

225. Datta, S.; Milner, J.D. Altered T-cell receptor signaling in the pathogenesis of allergic disease. J. Allergy Clin. Immunol. 2011, 127, 351-354. [CrossRef] [PubMed]

226. Lee, H.S.; Choi, E.J.; Choi, H.; Lee, K.S.; Kim, H.R.; Na, B.R.; Kwon, M.S.; Jeong, G.S.; Choi, H.G.; Choi, E.Y.; et al. Oral administration of 4-hydroxy-3-methoxycinnamaldehyde attenuates atopic dermatitis by inhibiting T cell and keratinocyte activation. PLoS ONE 2015, 10, e0144521. [CrossRef] [PubMed]

227. Kim, K.W.; Myers, R.A.; Lee, J.H.; Igartua, C.; Lee, K.E.; Kim, Y.H.; Kim, E.J.; Yoon, D.; Lee, J.S.; Hirota, T.; et al. Genome-wide association study of recalcitrant atopic dermatitis in Korean children. J. Allergy Clin. Immunol. 2015, 136, 678-684. [CrossRef] [PubMed]

228. Hussein, Y.M.; Alzahrani, S.S.; Alharthi, A.A.; Alhazmi, A.S.; Ghonaim, M.M.; Alghamdy, A.A.; El Askary, A. Gene polymorphism of interleukin-4, interleukin-4 receptor and STAT6 in children with atopic dermatitis in Taif, Saudi Arabia. Immunol. Investig. 2016, 45, 223-234. [CrossRef] [PubMed]

229. Chen, Y.Q.; Shi, H.Z. CD28/CTLA-4-CD80/CD86 and ICOS-B7RP-1 costimulatory pathway in bronchial asthma. Allergy 2006, 61, 15-26. [CrossRef] [PubMed]

230. Melnik, B.C. Does therapeutic intervention in atopic dermatitis normalize epidermal notch deficiency? Exp. Dermatol. 2014, 23, 696-700. [CrossRef] [PubMed]

231. Melnik, B.C. The potential role of impaired notch signalling in atopic dermatitis. Acta Derm. Venereol. 2015, 95, 5-11. [CrossRef] [PubMed] 
232. Zhang, Q.; Wang, C.; Liu, Z.; Liu, X.; Han, C.; Cao, X.; Li, N. Notch signal suppresses toll-like receptor-triggered inflammatory responses in macrophages by inhibiting extracellular signal-regulated kinase 1/2-mediated nuclear factor $\mathrm{kB}$ activation. J. Biol. Chem. 2012, 287, 6208-6217. [CrossRef] [PubMed]

233. Bailis, W.; Yashiro-Ohtani, Y.; Fang, T.C.; Hatton, R.D.; Weaver, C.T.; Artis, D.; Pear, W.S. Notch simultaneously orchestrates multiple helper $t$ cell programs independently of cytokine signals. Immunity 2013, 39, 148-159. [CrossRef] [PubMed]

234. Wilson, S.R.; The, L.; Batia, L.M.; Beattie, K.; Katibah, G.E.; McClain, S.P.; Pellegrino, M.; Estandian, D.M.; Bautista, D.M. The epithelial cell-derived atopic dermatitis cytokine TSLP activates neurons to induce itch. Cell 2013, 155, 285-295. [CrossRef] [PubMed]

235. Elias, P.M.; Hatano, Y.; Williams, M.L. Basis for the barrier abnormality in atopic dermatitis: Outside-inside-outside pathogenic mechanisms. J. Allergy Clin. Immunol. 2008, 121, 1337-1343. [CrossRef] [PubMed]

(C) 2016 by the authors; licensee MDPI, Basel, Switzerland. This article is an open access article distributed under the terms and conditions of the Creative Commons Attribution (CC-BY) license (http://creativecommons.org/licenses/by/4.0/). 